Lithos

March 2015, Volumes 218-219, Pages 22-36

http://dx.doi.org/10.1016/..lithos.2015.01.009

http://archimer.ifremer.fr/doc/00250/36121/

(c) 2015 Elsevier B.V. All rights reserved.

\title{
Origin and significance of tourmalinites and tourmaline- bearing rocks of Menderes Massif, western Anatolia, Turkey
}

\author{
Yücel-Öztürk Yeşim ${ }^{1}{ }^{\star}$, Helvacı Cahit ${ }^{1}$, Palmer Martin R. ${ }^{2}$, Ersoy E. Yalçın ${ }^{1}$, Freslon Nicolas ${ }^{2,3}$
}

${ }^{1}$ Dokuz Eylül Üniversitesi, Mühendislik Fakültesi, Jeoloji Mühendisliği Bölümü, TR-35160 İzmir, Turkey

${ }^{2}$ School of Ocean and Earth Science, University of Southampton, NOC, European Way, Southampton

SO14 3ZH, UK

${ }^{3}$ Département Géosciences Marines, IFREMER, 29280 Plouzanné, France

* Corresponding author : Yeşim Yücel-Öztürk, Tel.: + 9023230173 59; fax: + 902324531129 ; email

address : yesim.yucel@deu.edu.tr

\begin{abstract}
:
In the western central portion of Anatolia lies the Menderes Massif - a large metamorphic crystalline complex made of Neoproterozoic to Precambrian basement rocks overlain by Palaeozoic to early Tertiary metasedimentary rocks, and with a multistage metamorphic evolution developed from the late Neo-Proterozoic to Eocene. We have undertaken a study of the petrology, geochemistry and boron isotope composition of these tourmaline occurrences aiming to constrain the processes responsible for the enrichment of boron and other fluid mobile elements in the Menderes Massif. The dispersed tourmaline has chemical and boron isotope compositions typical of a continental crust setting, but while some of the tourmalinites display similar signatures, others have heavier boron isotope compositions (up to $+7.5 \%$ ). We suggest that the tourmalinites with continental characteristics formed part of the original Pan African basement rocks, whereas those with heavier $\delta 11 \mathrm{~B}$ signatures formed by later metamorphism during the Alpine orogeny, possibly through interaction with subduction-like fluids. This proposed process may also have been coincident with metasomatism of the lithospheric mantle beneath the massif, which is known to have experienced multistage metasomatism and enrichment history up to Neogene time.
\end{abstract}

\section{Highlights}

- A geochemical study of the tourmaline-rich rocks from the Menderes Massif $\rightarrow$ The tourmaline samples are grouped into tourmalinites, metasediments and gneisses. The tourmalines fall between the dravite and schorl classifications. $\delta^{11} \mathrm{~B}$ values of tourmalines of the metamorphic rocks resemble of the clastic origin. $\delta^{11} \mathrm{~B}$ values of the tourmalinites samples extend to much heavier values. 
Keywords : Tourmalinites, geochemistry, boron isotope, Menderes Massif, western Anatolia, Turkey

\section{Introduction}

Tourmaline is a common accessory mineral in a variety of lithologies and mineral deposits; including, granitic rocks (Neiva, 1974), sedimentary and metamorphic rocks (Henry \& Guidotti, 1985), tourmalinites (Ethier \& Campbell, 1977), and stratabound and stratiform mineral deposits (Slack, 1996). Tourmaline can accommodate a wide variety of major and trace elements (e.g., Dutrow \& Henry, 2011). Hence, the chemistry and isotopic composition of tourmaline has yielded 
valuable information concerning the origin of this mineral and its host rocks (Slack et al., 1989; Byerly \& Palmer, 1991; Palmer, 1991; Jiang et al., 1998) and this study aims to examine the B isotopic variations of tourmaline-rich occurrences in the metamorphic rocks of the Menderes Massif, western Anatolia.

Within the Menderes Massif of western Anatolia, Turkey (Fig. 1), tourmaline-rich rocks are associated with augen gneiss, leucogranite and garnet-mica schist, as part of a complex geologic setting that underwent polyphase deformation and low- to high-grade regional metamorphism during the Pan-African to Alpine orogenic events (Şengör et al., 1984; Mittwede et al., 1992; Oberhänsli et al., 1997; Dora et al., 2001; Candan et al., 2001, 2011; Whitney \& Bozkurt 2002; Régnier et al., 2003). The genesis of these tourmaline-rich rocks within the Pan-African basement rocks of the Menderes massif is, however, controversial. On the basis of field and major element data previous studies have identified the tourmaline-rich rocks as having either a sedimentary (stratiform/stratabound tourmalinites) and/or magmatic origin (Mittwede et al., 1993; Bozkurt et al., 2006; Candan et al., 2011). Hence, we have undertaken a geological, mineralogical, and geochemical study (B isotopic compositions in addition to major and trace element data) of tourmaline-rich rocks from the Menderes Massif in order to assess whether fresh insights can be gained into the geological evolution of the region. Tourmaline is particularly useful in this context because it is a robust mineral that can retain a record of regional geologic processes (e.g., van Hinsberg et al., 2011) and an understanding of the geologic history of the Menderes Massif is also important to interpretations of the pre- and post-collisional geodynamic evolution of the wider western Anatolia region.

\section{Geologic setting of the Menderes Massif}

In western Anatolia, the Anatolides including the Menderes Massif, collided with the Sakarya continental block along the İzmir-Ankara Zone (Okay et al., 2001). The northern edge of the 
Anatolide-Tauride platform, the Tavşanlı Zone, was subducted beneath the ophiolitic mélange rocks of the İmir-Ankara Zone and the Sakarya Zone at 88 Ma (Sherlock et al. 1999). This stage of continental collision resulted in crustal imbrication, accretion and thickening (Şengör and Y1lmaz, 1981; Whitney et al. 2008).

The Menderes Massif constitutes a regional, NE-SW-trending, roughly elliptical metamorphic terrain of $30000 \mathrm{~km}^{2}$, which is made up of Pan-African basement (Precambrian core series) and overlying Palaeozoic-early Tertiary metasedimentary units (cover series) (Fig. 1; Şengör et al., 1984; Candan et al., 2011). The Menderes Massif is tectonically overlain by rocks of the Izmir-Ankara zone and Cycladic complex to the north and west, and the Lycian Nappe sequence to the south (Şengör \& Y1lmaz 1981).

The Pan-African basement rocks (the core series) of the massif is composed of metasediments (paragneisses and schists) which were intruded by Pan-African plutons (orthogneisses; 550 Ma; see Candan et al. 2011) and metagabbros. The metasedimentary rocks are considered to have been deposited between 590-580 Ma (Late Proterozoic) in a passive continental margin setting (Candan et al. 2011). There are several tourmaline occurrences in the core series: (a) stratiform/stratabound tourmalinites, (b) tourmalines related to Pan-African leucogranites and (c) tourmalines within the metasediments. The cover units unconformably overly the core series (Supra-Pan African unconformity) along the Gökçay metagonglomerate (Candan et al., 2011) and are made up of; (a) Palaeozoic schist and Permian-Carboniferous phyllite, which are intruded by Triassic granites (Koralay et al. 2001), and (b) Upper Triassic micaschist and metaconglomerate with mafic intercalations, and Upper Cretaceous pelagic marble and Palaeocene-Eocene flysch (Özer et al. 2001; Candan et al. 2011).

The core units of the Menderes Massif were affected by granulite ( 583 Ma), eclogite ( 530 Ma) and amphibolite (greenschist facies to migmatisation conditions) facies metamorphism ( 550-540 Ma) 
related to the Pan-African orogeny (cf., Oberhänsli et al., 1998; Koralay et al., 2006; Candan et al., 2011). The entire Menderes Massif was also affected by regional mid-pressure and low temperature/high pressure metamorphic events developed during the late Cretaceous-late Eocene Alpine orogeny (known as main Menderes metamorphism) that was responsible for its internal imbrication and development of the last-stage of regional foliation (Şengör et al., 1984; Satır \& Friedrichsen, 1986; Bozkurt \& Park, 1999; Bozkurt and Satır, 2000; Candan et al., 2001; Whitney and Bozkurt, 2002; Rimmelé et al., 2003).

\section{Field relations and petrography of tourmaline-rich rocks}

Tourmaline is widespread in the orthogneisses and metasediments belonging to core series of the Menderes Massif. Tourmaline occurrences are observed as; fine-grained crystals within stratabound/stratiform tourmalinites in metasediments, disseminated crystals in metasediments and orthogneiss, large crystals in pegmatitic rocks of the orthogneisses, fracture-fillings in veins with quartz, and massive lenses within the orthogneiss. The petrographic features of the tourmaline occurrences vary, and allow its classification into three groups, depending on the host rock lithology; namely, (1) tourmalinites (from Karahayıt and Yeşilköy districts), (2) orthogneiss-hosted tourmaline (from Bozcakaya, Çulhalar, Irmadan and Salavatlı districts), and (3) metasediment-hosted (Labraunda district) tourmaline (Table 1). Sample localities are shown on Figure 1.

\subsection{Tourmalinites}

\subsubsection{Karahayıt and Yeşilköy districts}

In both the Karahayit and Yeşilköy districts, the dark brown colour of the tourmalinite outcrops contrasts with the generally light-coloured country rocks (mica+quartz \pm garnet schist). The tourmalinites in these areas occur as locally significant, but discontinuous, lenses or intercalations within mica-quartz ( \pm garnet) schist that grades into the micaceous quartzite and garnet schist. The stratiform tourmalinites and quartz-tourmaline rocks vary in thickness from a few centimetres to as 
much as 2-3 $\mathrm{m}$ in the Karahayıt and Yeşilköy districts (Figs. 2a-d and Figs. 2e-f, respectively). In the Karahayit area (Fig. 2a), the tourmalinites can be traced discontinuously for up to $2 \mathrm{~km}$ along strike, where they grade locally into tourmaline-free, quartzo-feldspathic schist. These tourmaline occurrences are readily distinguished from tourmaline-bearing veins because they do not cross-cut the relic sedimentary bedding. Although metamorphic remobilisation of boron (e.g. van Hinsberg et al 2011) has produced small local discordant quartz-tourmaline veins and segregations (Fig. 2b), the Karahayit tourmalinites mainly form concordant beds and lenses with the schistosity of mica-quartz ( \pm garnet) schists. No obvious signs of tourmaline breakdown were observed in study of thin sections of any of the tourmaline occurrences (Fig. 3), suggesting that this remobilisation was localised and not widespread across the massif. While it is likely that other fluid mobile elements were also mobilised during metamorphism, boron is unusual among such elements in that any remobilised boron is readily reincorporated in secondary tourmaline rather than being lost from the system (Slack et al., 1993). There are also folded tourmaline bands associated with crenulated tourmaline-bearing pelitic metasediments from the Karahayıt region (Fig. 2c) and the Yeşilköy region (Fig. 2f). They also form well-defined layers parallel to the foliation, and are characterised by alternating bands of quartz and fine-grained tourmaline that are characteristic of stratiform tourmalinites (Ethier \& Campbell, 1977). In this area, tourmalinites preserve syn-sedimentary features, such as planar bedding, graded bedding, fine-scale cross laminations, and rip-up clasts (Fig. 2d). Locally, the tourmalinite is almost completely dominated by tourmaline, accompanied only by irregular quartz veinlets (Fig. 2a). There are also coarse-grained tourmaline occurrences with quartz as $\sim 5 \mathrm{~cm}$-thick veins in metasediments and augen gneisses in Karahayıt (sample 72) and Yeşilköy (sample 83A) areas, respectively. A 1m-thick, banded tourmalinite lens (sample 74) occurs in metasediment $\sim 300 \mathrm{~m}$ SW of Karahayit village, where it is overlain by dolomitic limestone.

Petrographic study of 33 thin sections from the Karahayıt and Yeşilköy districts reveals that the mineralogy of the tourmalinites is dominated by tourmaline and quartz, with the former constituting 
$>15-20 \%$ by volume (Figs. 3a-g). Trace amounts of muscovite are common; accessory minerals include biotite, garnet, zircon, and apatite. Both the tourmaline and quartz are fine-grained $(<0.1$ $\mathrm{mm}$ ), and the tourmaline lacks inclusions of quartz or other minerals. In oriented thin sections tourmaline displays a granoblastic texture with interlobate to polygonal grain boundaries. Some tourmalinites contain alternating tourmaline- and quartz-rich laminae; in others, the tourmaline crystals may be crosscut by quartz microfractures (Figs. 3a and 3e). The most common texture is bedding defined by changes in the proportions of tourmaline and quartz.

The mineralogy, grain size, and structure of tourmalinites in the Yeşilköy area are similar to those in Karahayit, with the exception that the former are garnetiferous (Figs $3 \mathrm{f}$ and $3 \mathrm{~g}$ ). Most tourmaline grains are optically unzoned, but in a few thin sections some tourmalines have dark brown interiors and paler rims (Fig. 3b). Garnet in the Yeşilköy tourmalinites occurs as euhedral-subhedral crystals with abundant inclusions of quartz and tourmaline (Fig. 3f, g). This observation indicates that the tourmalinites in the Yeşilköy area are either coeval with, or older than, the regional metamorphism.

\subsection{Orthogneiss-hosted tourmalines}

\subsubsection{Bozcayaka (Ödemiş) district}

The Bozcayaka district, which is located in the Küçük Menderes graben in the middle of the Menderes Massif (Fig. 1), consists mainly of medium- to low-grade staurolite-bearing schist, marble, and quartzite, together with unusual cinnabar deposits at Çamlıca and Destiman Tepe. The area also has lesser occurrences of hornblende-hypersthene-augite gabbros that contain ilmenite, arsenopyrite, and pyrite. The whole area is intensively block-faulted, in which the faults strike east-west and southeast-northwest. 


\subsection{2 Çulhalar district}

The Çulhalar (Aydın) area covers the northern part of the southern Menderes Massif to the south of the Büyük Menderes graben (Fig. 1). The lithologies comprise mainly leucocratic tourmaline orthogneiss, biotite orthogneiss and garnet-mica schist / biotite albite schist of the Pan-African basement and phyllite-arenitic, quartzites-marble intercalation of the cover series. The orthogneiss is medium- to coarse-grained, and composed mainly of quartz, orthoclase, plagioclase, muscovite, biotite, and tourmaline, with accessory hematite, magnetite, allanite, zircon, rutile, and apatite. Tourmaline is most commonly found along the margins of the gneisses (Figs 2i-m). The tourmaline is coarse-grained (Figs. 2k, 2l) and shows poorly-developed foliation (Fig. 2j). The mica and almandine schist contains quartz, muscovite, biotite, albite, oligoclase, almandine, graphite, magnetite, hematite, titanite, apatite, tourmaline, and zircon. Lens-shaped bodies of marble are also found within the schist.

\subsubsection{Irmadan district}

In the Irmadan district, the dominant lithologies are paragneiss of sedimentary origin and augen gneiss of granitic origin of the Pan-African basement of the Menderes Massif. The orthogneiss cuts the sedimentary varieties in the form of dikes and stocks. The paragneiss is considered to be the oldest lithology of the Menderes crystalline sequence. Two types of orthogneisses are observed in the basement of the Menderes Massif; biotite orthogneiss and leucocratic tourmaline orthogneiss (Koralay et al. 2012). The leucocratic orthogneiss that hosts the tourmaline is coarse-grained and shows poorly-developed foliation (Figs. 2n and 2o). Its principal constituents are quartz, feldspar, biotite, muscovite, and garnet. The leucocratic tourmaline orthogneiss is light grey and massive, with relatively fine-grained margins and augen coarsening away from the contact zones. Trace amounts of tourmaline occur as glomerocrysts close to wallrock contacts (Fig. 3j). In addition to tourmaline, the dominant mineralogy is quartz, feldspar, and muscovite, with minor apatite, zircon, rutile, and opaque minerals. 


\subsubsection{Aydın-Salavatll district}

The Salavatlı district is located in the middle of the Büyük Menderes graben (Fig. 1) and contains metamorphic rocks, including orthogneiss, paragneiss and schist of the core series. Poorly-defined layers $\sim 1 \mathrm{~cm}$ thick composed of anhedral to subhedral tourmaline crystals occur locally within strongly sheared granitic gneiss near Eskihisar (Aydın-Sultanhisar) at Beypazit Tepesi. This tourmaline occurrence lies within a normal fault zone (the Salavatll fault) in rocks that are best characterised as protomylonite or mylonite gneiss. Approximately $100 \mathrm{~m}$ upslope from this site, but still within the fault zone, undeformed tourmaline-bearing granitic pegmatites cut metasedimentary rocks (Figs. $2 \mathrm{p}$ and $2 \mathrm{r}$ ). At this locality, the tourmaline forms coarse-grained $(2-7 \mathrm{~mm})$, euhedral to subhedral crystals (Fig. 3k). It is possible that these pegmatites were sourced from the underlying, sheared granitic gneiss (Mittwede et al., 1992).

\subsection{Metasediment-hosted tourmalines}

\subsubsection{Labraunda district}

The Labraunda region lies in the southern part of the Menderes Massif (Fig. 1). The dominant lithology is gneiss that is thought to have originated from calc-alkaline granitic rocks of the core rocks of the Menderes Massif. The region also contains garnet-mica schist, chlorite schist, and marble, in which tourmaline occurs as disseminated grains and rare tourmalinites (Figs. 2s-v).

\section{Analytical methods}

\subsection{Whole rock ICP-MS analyses}

Sample powders $(\sim 50 \mathrm{mg})$ were dissolved in $\mathrm{HF} / \mathrm{HNO}_{3}$ in sealed Teflon vials. The solutions were evaporated to dryness at $150^{\circ} \mathrm{C}$ and the residue digested in $\mathrm{HF} / \mathrm{HNO}_{3}$. They were then heated for a further 5 days at $170^{\circ} \mathrm{C}$ in sealed vessels, before being dried and dissolved in $\mathrm{HNO}_{3}$ prior to ICP-MS 
analysis. The data are reported in Table 4. No visible residues were observed after the digests and there is good agreement between the reported and accepted values for the various standards analysed (Table 5).

\subsection{Electron microprobe analyses}

Tourmaline compositions were determined using a Jeol Super 733 electron microprobe at the Geological Institute, University of Copenhagen, using the following standards; olivine, corundum, wollastonite, and hematite. The operating conditions were; accelerating voltage $15 \mathrm{kV}$, beam current $20 \mathrm{nA}$, beam diameter $5 \mu \mathrm{m}$, and WDS detection. Analyses were also performed on a Camebax electron microprobe at the University Pierre at Marie Curie, Paris, using the same standards and operating conditions, apart from the beam current that was $10 \mathrm{nA}$. A total of 26 thin sections from different locations were investigated and 413 separate analyses were obtained.

\subsection{Boron isotope analyses}

Boron isotopic ratios were determined on in-situ tourmaline grains that are optically unzoned, in 100 $\mu$ m-thick sections of 22 samples by laser ablation multi-collector inductively coupled plasma mass spectrometry (LA-ICP-MS) at the University of Southampton according to the method described in detail by Ribeiro da Costa et al. (2014). Laser ablation was carried out using a New Wave $193 \mathrm{~nm}$ ArF Eximer laser with a standard $\sim 30 \mathrm{~cm}^{2}$ cell and $100 \%$ mixed $\mathrm{He}$ (mixed with $\mathrm{Ar}+\mathrm{N}_{2}$ after the cell). The laser was focussed to a $25 \mu \mathrm{m}$ spot, with a fluence of $\sim 5 \mathrm{~J} / \mathrm{cm}^{2}$ and a $4 \mathrm{~Hz}$ repetition rate; the beam was rastered along a 100-200 $\mu \mathrm{m}$ line (at $10 \mu \mathrm{m} / \mathrm{sec}$ ). NIST 610 glass was analysed between each sample. Tourmaline data are normalised to the $\delta^{11} \mathrm{~B}$ value of $-1.05 \%$ reported for NIST 610 (Kasemann et al., 2009). The average internal precision for each tourmaline analysis is between $\pm 0.1 \%$ and $\pm 0.3 \%$ ( 2 s.d). Each tourmaline sample was analysed three times: average reproducibility of the three analyses is $\pm 0.4 \%$ ( 2 s.d). 
Analyses were also determined on 18 tourmaline samples previously analysed for $\delta^{11} \mathrm{~B}$ values by Palmer and Slack (1989) using thermal ionization mass spectrometry (TIMS). A comparison of the data derived from two separate days' LA-MC-ICP-MS analyses and the TIMS data is shown in Figure 4. The $\delta^{11} \mathrm{~B}$ values derived from the two methods are not completely comparable because the TIMS technique involved analysis of the total boron extracted from grains of tourmaline separated from their host rock, whereas the LA-MC-ICPMS technique only analyses a small portion of individual tourmaline grains, and several of the samples analysed by Palmer and Slack (1989) showed optical and isotopic zoning. Nevertheless, the average difference between the $\delta^{11} \mathrm{~B}$ values derived from the two methods (over a $\delta^{11} \mathrm{~B}$ range of -24.5 to $+3.2 \%$ determined by TIMS) is only $0.7 \%$ (maximum deviation of $2.3 \%$ ); 15 of the 18 analyses differ by $<1 \%$. It is important to note that none of the tourmaline grains analysed from the Menderes Massif show isotopic zoning within the levels of uncertainty listed in Table 3.

\section{Results}

Representative electron microprobe analyses of tourmaline from the three groups are listed in Table 2. In most samples, individual tourmaline grains are chemically homogenous, with only minor variations in composition. Notable exceptions are samples L-3 (Labraunda) and K-1 (Karahayit). The latter shows a range in $\mathrm{MgO}$ from 4.49 to $10.65 \mathrm{wt} \%, \mathrm{FeO}$ from 3.28 to $10.57 \mathrm{wt} \%$ to, $\mathrm{CaO}$ from 0.73 to $1.61 \mathrm{wt} \%$ and $\mathrm{Na}_{2} \mathrm{O}$ from 1.26 to $2.93 \mathrm{wt} \%$.

The tourmalines analysed from the Menderes Massif fall roughly equally between the dravite (Mgrich) and schorl (Fe-rich) end members, with no significant uvite or feruvite component (Fig. 5). Despite the large number of permissible substitutions, some generalisations can be made about the relationship between tourmaline composition and host rock type. On the ternary plots of Henry and Guidotti (1985), the data fall largely in the host rock field described as metapelites and 
metapsammites not coexisting with an Al-saturating phase (Field 5) on the $\mathrm{Al}-\mathrm{Fe}_{(\mathrm{tot})}-\mathrm{Mg}$ diagram (Fig. 6a), and between the fields described as Li-poor granitic rocks (Field 2) and Ca-poor metapelites, metapsammites, and quartz-tourmaline rocks (Field 8) on the $\mathrm{Ca}-\mathrm{Fe}_{(\mathrm{tot})}-\mathrm{Mg}$ diagram (Fig. 6b).

The basic formula of tourmaline can be written as $\mathrm{XY}_{3} \mathrm{Z}_{6}\left(\mathrm{~T}_{6} \mathrm{O}_{18}\right)\left(\mathrm{BO}_{3}\right) \mathrm{V}_{3} \mathrm{~W}$, where $\mathrm{X}=\mathrm{Na}, \mathrm{Ca}, \mathrm{K}$, vacancy; $\mathrm{Y}=\mathrm{Fe}^{2+}, \mathrm{Mg}, \mathrm{Mn}^{2+}, \mathrm{Li}, \mathrm{Al}, \mathrm{Cr}^{3+}, \mathrm{V}^{3+}, \mathrm{Fe}^{3+},\left(\mathrm{Ti}^{4+}\right) ; \mathrm{Z}=\mathrm{Mg}, \mathrm{Al}, \mathrm{Fe}^{3+}, \mathrm{V}^{3+}, \mathrm{Cr}^{3+} ; \mathrm{T}=\mathrm{Si}, \mathrm{Al}$, (B); V = OH, O; W = OH, F, O (Hawthorne \& Henry, 1999; Dutrow \& Henry, 2011). Chemical substitutions in tourmaline mainly occur in the X, Y, and Z sites (Foit \& Rosenberg, 1977; Rosenberg \& Foit, 1979; Henry \& Guidotti, 1985; Grice \& Robinson, 1989). On an Al versus $(\mathrm{Fe}+\mathrm{Mg}+\mathrm{Mn}+\mathrm{Ti})$ plot, the data define a linear trend (Fig. 7). Approximately half of the samples have Al contents $>6$ atoms per formula unit (apfu), which are sufficient to account for a full six cations in the $\mathrm{Z}$ site, with the excess $\mathrm{Al}$ located in $\mathrm{Y}$ site due to alkali defect and/or dehydroxylation-type substitutions. Tourmalines having $<6$ apfu, largely from the tourmalinites, imply some $\mathrm{Fe}^{3+}$ substitution for $\mathrm{Al}$ in the $\mathrm{Z}$ site. As tourmalinites commonly form by metasomatism of aluminous sediments by boron-rich fluids (Slack, 1996), the chemistry of this type of tourmaline is also partly dependent on the bulk composition of the original sediments, in which tourmalines that form in an environment lacking an Al-saturating phase have low Al contents (Gallagher, 1988).

In general, $\mathrm{Mg}$ and $\mathrm{Al}$ contents of the tourmalines range from 0.27 to $2.78 \mathrm{apfu}$ and from 5.37 to 6.00 , respectively. The tourmalines have high $\mathrm{Fe}^{2+}(0.59-2.78 \mathrm{apfu})$ and are consistent with compositional variability in accordance with $\mathrm{MgFe}^{2+}{ }_{-1}$ (Figs. 8a, b). There is a general inverse correlation between $\mathrm{Mg}$ and $\mathrm{Fe}$. Plots of $\mathrm{Mg}-\mathrm{Fe}$ and $\mathrm{Al}-\mathrm{Fe}$ show that the compositional variation of the tourmaline is primarily along the schorl-dravite join (Figs. 8a, b).

Boron isotope values for tourmalines from the Menderes Massif measured in this study are listed in Table 3 as $\delta^{11} \mathrm{~B}$ values relative to NBS boric acid SRM 951. The data are illustrated as histograms 
for the three different tourmaline types in Figure 9, spanning a wide range -8.0 to $+6.4 \%$ ); tourmalines from the metasediments and gneisses have a more restricted range (-8.0 to $-3.9 \%$ ) than those from the tourmalinites $(-5.7$ to $+6.4 \%)$.

The trace elements/REE values for tourmaline from the Menderes Massif are listed in Table 4. Chondrite-normalized (Taylor and McLennan, 1985) rare earth element patterns of tourmalinites (solid lines) and gneisses and metasediments (dashed lines) of tourmaline-bearing rocks from the Menderes Massif are shown in Figure 10. Comparison of the rare earth element patterns of the tourmalinite-bearing rocks with those of the gneisses and metasediments show generally consistent trends. Furthermore, the ratio of two immobile elements $\left(\mathrm{Nb} / \mathrm{Al}_{2} \mathrm{O}_{3}\right)$ is statistically indistinguishable between the two groups (Fig. 11a). The tourmalinite-bearing rocks show depleted $\mathrm{K}_{2} \mathrm{O} / \mathrm{Al}_{2} \mathrm{O}_{3}$ (Fig. 11b) and elevated $\mathrm{MgO} / \mathrm{Al}_{2} \mathrm{O}_{3}$ ratios (Fig. 11c) relative to the gneisses and metasediments. However the tourmalinites consistently exhibit more positive $\mathrm{Eu}$ anomalies than the gneisses and metasediments (Fig. 11d)

\section{Discussion and Conclusions}

Previous studies (Mittwede et al., 1992, 1993; Bozkurt et al., 2006) revealed that three main occurrences of tourmaline exist in the core rocks of the Menderes Massif: (a) stratiform/stratabound tourmalinites and (b) tourmalines in metasediments; and (c) magmatic tourmalines in orthogneisses. Tourmalinites in the metasediments display; (1) laterally continuous mm-scale quartz and tourmaline laminae, (2) tourmaline-rich rip-up clasts, (3) distinct angular quartz grains, and (4) graded- and cross-bedding structures that are indicative of metasomatism of aluminous sediments by boron-rich fluids (Slack, 1996) and cannot be related solely to granitoid magmatism. However, the origin of the tourmalinites which have thicknesses up to 2-3 m extending up to $2 \mathrm{~km}$ in length remains unclear. Furthermore, the B isotopic data in this study shows a clear distinction between the $\delta^{11} \mathrm{~B}$ values obtained from these tourmalinites and the other tourmaline occurrences. 
The $\delta^{11} \mathrm{~B}$ values of tourmalines from different environments are illustrated in Figure 9. These values indicate that the Menderes Massif tourmalines from the metasediments and gneisses have $\delta^{11} \mathrm{~B}$ values $(-8.1$ to $-3.9 \%)$ that are typical of tourmalines from clastic metasedimentary rocks (-15 to 0 \%o) (Palmer \& Slack, 1989; Palmer \& Swihart, 1996), whereas values of the Menderes Massif tourmalinites extend to much heavier values (up to $+6.5 \%$ ). High $\delta^{11} \mathrm{~B}$ values have been observed in tourmalines associated with metaevaporites (up to $+18.3 \%$; Palmer $\&$ Slack, 1989). Both marine and non-marine evaporites are abundant throughout Anatolia (although none is recorded in the Menderes Massif); however, borate minerals are rare in marine facies (Palmer et al., 2004) and those analysed from non-marine settings in Anatolia have $\delta^{11} \mathrm{~B}$ values in the range -25 to $-2 \%$ (Palmer $\&$ Helvac1, 1995; 1997). Because the boron isotope composition of tourmaline is more negative than the fluid from which it crystallises (Palmer et al., 1992), dissolution of Anatolian borates and reprecipitation of the boron in tourmaline could not yield the elevated $\delta^{11} \mathrm{~B}$ values in most tourmalinite samples from this study. Fig. 12 shows the variation of $\delta^{11} \mathrm{~B}$ values with some of the main chemical variables of tourmaline. Overall, the data in Fig. 12 show no obvious correlations between the $\delta^{11} \mathrm{~B}$ values and chemical composition of the tourmaline.

Very heavy $\delta^{11} \mathrm{~B}$ values $(+18$ to $+28 \%$ ) have been found in tourmaline from the nearby Greek island of Syros (Marschall et al., 2006). In this area, tourmaline occurs along the margins of tectonic blocks enclosed in a high-pressure, subduction-zone mélange, where it formed during Eocene exhumation (Trotet et al., 2001) of the mélange by the influx of fluids derived from the subducting sediments and underlying slab. Marschall et al. (2006) suggest that the deep-seated fluids started out with a $\delta^{11} \mathrm{~B}$ value of $+8 \%$ and a $\mathrm{B}$ concentration of $700 \mathrm{ppm}$ during ascent from the slab. As the fluids rose through the mélange, boron was successively partitioned into the solid phase, leading to preferential removal of ${ }^{10} \mathrm{~B}$ from solution, such that when the fluids reached the site of tourmaline formation, boron concentrations had dropped to $100-300 \mathrm{ppm}$ and fluid $\delta^{11} \mathrm{~B}$ values had risen to +18 to $+28 \%$. The solid phase responsible for preferential uptake of ${ }^{10} \mathrm{~B}$ in the Syros study was not 
unambiguously identified, but Marschall et al. (2006) suggest that it was most likely comprised of serpentine, mica and amphiboles in which the boron is tetrahedrally co-ordinated. An alternative, but related, explanation for the heavy $\mathrm{d}^{11} \mathrm{~B}$ values observed on Syros is that there were derived from the dehydration of subducted serpentinites formed at the slab-mantle interface during the early stages of slab subduction (Scambelluri and Tonarini, 2012). While the tectonic settings of Syros and the Menderes Massif are not identical, both involved continental collision and subduction of oceanic crust, so while there will be difference in details of the two systems (e.g. mineralogy of boronbearing phases, reaction temperatures, water/rock ratios, etc.) they are sufficiently alike to warrant comparison and draw analogies.

Following collision between the Sakarya and Anatolides continental blocks, the Menderes Massif underwent regional deformation and internal imbrication during its final metamorphism (main Menderes metamorphism (Şengör and Y1lmaz, 1981; Rimmelé et al. 2003). The imbrication during crustal thickening in an active subduction zone setting may have played an important role in the formation of the tourmalinites, such that the tourmaline $\delta^{11} \mathrm{~B}$ data can be interpreted in terms of the following model. Prior to the collisional event, the Menderes Massif contained dispersed tourmaline within continental crust and clastic sediments; represented today by the metasediment and gneiss samples. These tourmalines have $\delta^{11} \mathrm{~B}$ values of -8 to $-4 \%$ that are typical of tourmalines in continental crust and/or clastic metasedimentary settings (Palmer \& Slack, 1989).

Tourmalinites commonly form by metasomatism of Al-bearing lithologies by boron-rich fluids (Slack, 1996). Assessments of the net mass change involved in the formation of tourmalinites is best determined from mobile/immobile element ratio plots, but such an approach is only truly insightful if the pre-tourmalinization, unaltered protoliths have a narrow compositional range (Slack, 1996). This is clearly not the case in this study because (as described above) the Menderes Massif contains a wide range of variably metamorphosed lithologies as exemplified by the range in REE patterns and 
concentrations in both the tourmalinites and the metasediments and gneisses (Table 4 and Fig. 10). Nevertheless, comparison of the geochemical compositions of the tourmalinite-bearing rocks with those of the gneisses and metasediments show consistent trends. For example, the ratio of two immobile elements $\left(\mathrm{Nb} / \mathrm{Al}_{2} \mathrm{O}_{3}\right)$ is statistically indistinguishable between the two groups (Fig. 11a), whereas the tourmalinite-bearing rocks show depleted $\mathrm{K}_{2} \mathrm{O} / \mathrm{Al}_{2} \mathrm{O}_{3}$ (Fig. 11b) and elevated $\mathrm{MgO} / \mathrm{Al}_{2} \mathrm{O}_{3}$ ratios (Fig. 11c) relative to the gneisses and metasediments. These patterns are very similar to more tightly constrained mass balance studies of tourmalinite formation elsewhere (e.g. Slack et al., 1993; Shaw et al., 1993; Slack and Stevens, 1994). Interestingly, although there is a wide range in REE patterns and concentrations, the tourmalinites consistently exhibit more positive Eu anomalies than the gneisses and metasediments (Fig. 11d). Overall, therefore, these data are consistent with the tourmalinites having been formed by metasomatism of the gneisses and metasediments by acidic, relatively reducing, boron-rich fluids.

During collision and imbrication of the Menderes Massif, boron-rich fluids were expelled from the subduction zone and formed the tourmalinites with higher $\delta^{11} \mathrm{~B}$ values as the fluids flowed into structurally higher portions of the massif. Assuming that the fluids had $\delta^{11} \mathrm{~B}$ values similar to those proposed for the initial fluids in the Syros subduction setting (+8\%; Marschall et al., 2006), then precipitation of tourmalinites from these fluids at temperatures of $200-400^{\circ} \mathrm{C}$ (cf. Slack, 1996) would yield tourmaline crystals having $\delta^{11} \mathrm{~B}$ values of +7 to $+7.5 \%$ using the temperature-dependent boron isotope fractionation of Marschall et al. (2006), or -2 to $+4 \%$ using that of Palmer et al. (1992). As noted by Marschall et al. (2006), there are a large number of variable in this type of system that preclude an exact solution to any model. For example, application of the tourmaline-quartz oxygen isotope geothermometer (Zheng, 1993) to the tourmalinites is made complicated by the fine grain size of these rocks (Fig. 3d). The best fit to the Syros boron isotope data was obtained using a temperature of $400^{\circ} \mathrm{C}$, but the authors could not preclude temperatures as low as $200^{\circ} \mathrm{C}$ (Marschall et al., 2006). Regardless of the exact pressure and temperature conditions of tourmalinite formation in 
the Menderes Massif, if the hypothesis that the high $\delta^{11} \mathrm{~B}$ tourmalinites formed from subduction-zone fluids is correct, then these tourmalinites must be much younger (Eocene?) than their host rocks (570-520 Ma).

In this context, it is noteworthy that the early-middle Miocene volcanism of western Anatolia is characterized by the eruption of high potassium calc-alkaline and ultrapotassic rocks. The isotopic and geochemical characteristics of these rocks indicate that their parental magmas were sourced from lithospheric mantle that had been intensely metasomatised by large volumes of subduction-zone fluids and melts (Ersoy et al., 2010, 2012; Prelevic et al., 2012) or by continental subduction events during the accretion of continental and oceanic assemblages (Çoban et al., 2012; Ersoy et al., 2012). However, geodynamic models (Faccenna et al., 2003; Hafkenscheid et al., 2006) have also been used to argue that this metasomatism could not have arisen from the Aegean subduction zone (initiated at $13 \mathrm{Ma}$; Le Pichon \& Angelier, 1979), but must have occurred at some (unspecified) time prior to early-middle Miocene volcanism (Pe-Piper \& Piper, 2001; Ersoy et al., 2012). We suggest that this metasomatic event took place during the Late Palaeocene-Eocene internal imbrication and partial subduction of the Menderes Massif, and that expulsion of subduction-zone fluids resulted in metasomatism of the lithospheric mantle in the region and (at a structurally higher level) formation of the high- $\delta{ }^{11}$ B tourmalinites (Fig. 13). Subsequent slab roll back and/or lithospheric delamination processes in the Early Miocene (van Hinsbergen et al., 2010; Çoban et al., 2012; Ersoy et al., 2012) then led to asthenospheric inflow and melting of the previously metasomatised mantle to yield the characteristic potassium-rich volcanism of western Anatolia (Çoban et al., 2012; Ersoy et al., 2012).

In conclusion, on the basis of field and B-isotopic data, as well as previous observations, we suggest that tourmaline occurrences in the Menderes Massif include; (1) stratiform/stratabound tourmalines deposited in a passive margin during Proterozoic (deposition of the core sediments of the Menderes Massif); (2) tourmalines associated with the Pan-African granitic magmatism, and (3) tourmalinites 
(with high B isotopes) which were remobilized and emplaced during the late Cretaceous-late Eocene deformation and imbrication of the Menderes Massif.

\section{Acknowledgements}

The tourmalines were analysed on a microprobe at the Geological Institute, University of Copenhagen, Denmark and University Pierre et Marie Curie, Paris and we thank Peter Appel and Yves Fuchs for the analyses. We thank Matt Cooper, Agnes Michalik and Andy Milton, for assistance with the geochemical and boron isotope analyses. We are particularly grateful to John Slack, Rob Duncan, Dejan Prelevic and an anonymous reviewer for their helpful comments. This study was supported by two research project grants, (Project Number: 2010.KB. FEN.009) from Dokuz Eylül University Scientific Research Projects (BAP) and (Project number AIF 0.922.98.01.32) from Dokuz Eylul University Graduate School of Natural and Applied Sciences.

\section{References}

Altherr, R., Topuz, G., Marschall, H., Zack, T., Ludwig, T., 2004. Evolution of a tourmaline-bearing lawsonite eclogite from Elekdag area (Central Pontides, N Turkey): evidence for infiltration of slab-derived B-rich fluids during exhumation. Contributions to Mineralogy and Petrology, 148, 409-425.

Barth, S., 1993. Boron isotope variations in nature: a synthesis. Geologische Rundschau, 82, 640651.

Benton, L.D., Ryan, J.G., Tera, F., 2001. Boron isotope systematics of slab fluids as inferred from a serpentine seamount, Mariana forearc. Earth and Planetary Science Letters, 187, 273-282.

Bebout, G.E., Nakamura, E., 2003. Record in metamorphic tourmaline of subduction-zone devolatilization and boron cycling. Geology, 31, 407-410. 
Bozkurt E, Park R.G., 1994. Southern Menderes Massif: an incipient metamorphic core complex in Western Anatolia, Turkey. Journal of Geoological Society of London 151, 213-216.

Bozkurt, E., Park, R.G., 1999. The structure of the Palaeozoic schists in the southern Menderes Massif, western Turkey: A new approach to the origin of the main Menderes metamorphism and its relation to the Lycian nappes. Geodinamica Acta 12, 25-42.

Bozkurt, E., Satır, M., 2000. The southern Menderes Massif (western Turkey): geochronology and exhumation history. Geological Journal 35, 285-296

Bozkurt, E., Winchester, J.A., Mittwede, S.K., Ottley, C.J., 2006. Geochemistry and Tectonic Implications of Leucogranites and Tourmalines of the Southern Menderes Massif, Southwest Turkey. Geodinamica Acta 19, 363-390.

Bradley, D.C., 2008. Passive margins through earth history. Earth-Science Reviews 91, 1-26.

Byerly, G.R., Palmer, M.R., 1991. Tourmaline mineralization in the Barberton greenstone belt, South Africa: Early Archean metasomatism by evaporite-derived boron. Contributions to Mineralogy and Petrology 107, 387-402.

Candan, O., Dora, O.Ö., Oberhänsli, R., Çetinkaplan, M., Partzsch, J.H., Warkus, F.C., Dürr, S., 2001. Pan-African high-pressure metamorphism in the Precambrian basement of the Menderes Massif, western Anatolia, Turkey. International Journal of Earth Sciences 89, 793-811.

Candan, O., Koralay, E., Akal, C., Kaya, O., Oberhänsli, R., Dora, O.Ö., Konak, N., Chen, F., 2011. Supra-Pan-African unconformity between core and cover series of the Menderes Massif/Turkey and its geological implications. Precambrian Research 184, 1-23.

Chaussidon, M., Albare`de, F., 1992. Secular boron isotope variations in the continental crust: an ion microprobe study. Earth and Planetary Science Letters, 108, 229-241. 
Chaussidon, M. \& Jambon, A. 1994. Boron content and isotopic composition of oceanic basalts: Geochemical and cosmochemical implications. Earth and Planetary Science Letters, 121, $277-291$.

Chaussidon, M., Marty, B., 1995. Primitive boron isotope composition of the mantle. Science, 269, $383-386$.

Clift, P.D., Rose, E.F., Shimizu, N., Layne, G.D., Draut, A.E., Regelous, M., 2001. Tracing the evolving flux from the subducting plate in the Tonga-Kermadec arc system using boron in volcanic glass. Geochimica et Cosmochimica Acta, 65, 3347-3364.

Çoban, H., Karacık, Z., Ece, Ö.I., 2012. Source contamination and tectonomagmatic signals of overlapping early to middle Miocene orogenic magmas associated with shallow continental subduction and asthenospheric mantle flows in western Anatolia: A record from Simav (Kütahya) region. Lithos 140-141, 119-141.

Dora, O.Ö., Candan, O., Kaya, O., Koralay, E., Dürr, S., 2001. Revision of the so-called "leptite gneisses" in the Menderes Massif: supracrustal metasedimentary origin. International Journal of Earth Sciences 89, 836-851.

Dutrow, B.L., and Henry, D.J., 2011. Tourmaline: A geologic DVD. Elements 7, 301-306.

Erdoğan, B., Güngör, T., 2004. The problem of the core: cover boundary of the Menderes Masif and an emplacement mechanism for regionally extensive gneissic granite, Western Anatolia Turkey. Turkish Journal of Earth Sciences 13, 15-36.

Ersoy, E.Y., Helvac1, C., Palmer, M.R., 2010. Mantle source characteristics and melting models for the early-middle Miocene mafic volcanism in Western Anatolia: Implications for enrichment processes of mantle lithosphere and origin of K-rich volcanism in postcollisional settings. Journal of Volcanology and Geothermal Research 198, 112-128.

Ersoy, E.Y., Helvac1, C., Uysal, İ., Karaoğlu, Ö., Palmer, M.R., Dindi, F., 2012. Petrogenesis of the Miocene volcanism along the İzmir-Balıkesir transfer zone in western Anatolia, Turkey: 
Implications for origin and evolution of potassic volcanism in post-collisional areas. Journal of Volcanology and Geothermal Research 241-242, 21-38.

Ethier, V.G., Campbell, F.A., 1977. Tourmaline concentrations in Proterozoic sediments of the southern Cordillera of Canada and their economic significance. Canadian Journal of Earth Sciences 14, 2348-2363.

Faccenna, C., Jolivet, L., Piromallo, C., Morelli, A., 2003. Subduction and the depth of convection of the Mediterranean mantle. Journal of Geophysical Research 108, doi:10.1029/2001, JB001690.

Foit, F.F. Jr., Rosenberg, P.E., 1977. Coupled substitutions in the tourmaline group. Contributions to Mineralogy and Petrology 62, 109-127.

Gallagher, V., 1988. Coupled substitutions in schorl-dravite tourmaline: New evidence from SE Ireland. Mineralogical Magazine 52, 637-650.

Gessner, K., Piazolo, S., Güngör, T., Ring, U., Kröner, A., Passchier, C.W., 2001. Tectonic significance of deformation in granitoid rocks of the Menderes nappes, Anatolide belt, southwest Turkey. Int Journal of Earth Sciences 89, 766-780.

Gessner, K., Collins, A., Ring, U., Güngör, T., 2004. Structural and thermal history of a polyorogenic basement: $\mathrm{U} / \mathrm{Pb}$ geochronology of granitoids rocks in southern Menderes Masif, Western Turkey. Journal of Geological Society of London, 161, 93-101.

Grice, J.D., Robinson, G.W., 1989. Ferruvite, a new member of the tourmaline group, and its crystal structure. Canadian Mineralogist 27, 199-203.

Hafkenscheid, E., Wortel, M.J.R., Spakman, W., 2006. Subduction history of the Tethyan region derived from seismic tomography and tectonic reconstructions. Journal of Geophysical Research 111, B08401.

Hawthorne, F.C., Henry, D.J., 1999. Classification of the minerals of the tourmaline group. European Journal of Mineralogy 11, 201-215. 
Henry, D.J., Guidotti, C.V., 1985. Tourmaline as a petrogenetic indicator mineral: An example from the staurolite-grade metapelites of NW Maine. American Mineralogist 70, 1-15.

Ishikawa, T., Nakamura, E., 1992. Boron isotope geochemistry of the oceanic crust from DSDP/ODP Hole 504B. Geochimica et Cosmochimica Acta, 56, 1633-1639.

Ishikawa, T., Nakamura, E., 1994. Origin of the slab component in arc lava from across-arc variation of B and $\mathrm{Pb}$ isotopes. Nature, 370, 205-208.

Ishikawa, T., Tera, F., 1997. Source, composition and distribution of the fluid in the Kurile mantle wedge: constraints from across-arc variations of $\mathrm{B} / \mathrm{Nb}$ and $\mathrm{B}$ isotopes. Earth and Planetary Science Letters, 152, 123-138.

Ishikawa, T., Tera, F., Nakazawa, T., 2001. Boron isotope and trace element systematics of the three volcanic zones in the Kamchatka arc. Geochimica et Cosmochimica Acta, 65, 4523-4537.

Jiang, S.Y., Palmer, M.R., Slack, J.F., Shaw, D.R., 1998. Paragenesis and chemistry of multistage tourmaline formation in the Sullivan $\mathrm{Pb}-\mathrm{Zn}-\mathrm{Ag}$ deposit, British Columbia. Economic Geology 93, 47-67.

Kasemann, S., Erzinger, J. \& Franz, G. 2000. Boron recycling in the continental crust of the central Andes from the Paleozoic to Mesozoic, NW Argentina. Contributions to Mineralogy and Petrology, 140, 328-343.

Kasemann, S.A., Schmidt, D.N., Bijma, J., Foster, G.L., 2009. 452 In situ boron isotope analysis in marine carbonates and its application for foraminifera and palaeo-pH. Chemical Geology $260,138-147$.

Koralay O.E., Chen F, Oberhänsli R, Wan Y, Candan O (2006) Age of granulite facies metamorphism in the Menderes Massif, western Anatolia/Turkey: SHRIMP U-Pb zircon dating. In: 59th Geological Congres Turkey, Abstracts Book 28-29.

Koralay, O.E., Candan, O., Chen, F., Akal, C., Oberhänsli, R, Satır, M., Dora, O.Ö., 2012. PanAfrican magmatism in the Menderes Massif: geochronological data from leucocratic 
tourmaline orthogneisses in western Turkey. International Journal of Earth Sciences (Geol Rundsch) 101, 2055-2081.

Le Pichon, X., Angelier, J., 1979. The Hellenic arc and trench system: A key to the neotectonic evolution of the eastern Mediterranean area. Tectonophysics. 60 1-42.

le Roux, P.J., Shirey, S.B., Benton, L., Hauri, E.H. \& Mock, T.D. 2004. In situ, multiple-multiplier, laser ablation ICP-MS measurement of boron isotopic composition $\left(\delta^{11} \mathrm{~B}\right)$ at the nanogram level. Chemical Geology 203, 123-138.

Marschall, H.R., Ludwig, T., Altherr, R., Kalt, A., Tonarini, S., 2006. Syros metasomatic tourmaline: Evidence for very high- $\delta^{11} \mathrm{~B}$ fluids in subduction zones. Journal of Petrology 47, 19151942.

Marschall, H.R., Altherr, R., Kalt, A., Ludwig, T., 2008. Detrital, metamorphic and metasomatic tourmaline in high-pressure metasediments from Syros (Greece): intra-grain boron isotope patterns determined by secondary-ion mass spectrometry. Contributions to Mineralogy and Petrology, 155, 703-717.

Marschall, H.R., Korsakov, A.V., Luvizotto, G..L., Nasdala, L., Ludwig, T., $2009 . \quad$ On the occurrence and boron isotopic composition of tourmaline in (ultra)high-pressure metamorphic rocks. Journal of the Geological Society, 166,811-823.

Marschall, H.R., Ludwig, T., 2006. Re-examination of the boron isotopic composition of tourmaline from the Lavicky granite, Czech Republic, by secondary ion mass spectrometry: back to normal. Critical comment on 'Chemical and boron isotopic composition of tourmaline from the Lavicky leucogranite, Czech Republic’ by S.-Y. Jiang et al., Geochemical Journal, 37, 545-556, 2003. Geochemical Journal, 40, 631-638.

Mittwede, S.K., Helvac1, C., Karamanderesi, İ.H., Kun, N., Candan, O., 1992. Modes and implications of tourmaline occurrence in the Menderes Massif, western Anatolia, Turkey. 
Geosound, 1st International Symposium on Eastern Mediterranean Geology. 13-16 October 1992, İzmir, Special Issue, Geosound, 179-190.

Nakano, T., Nakamura, E., 2001. Boron isotope geochemistry of metasedimentary rocks and tourmalines in a subduction zone metamorphic suite. Physics of the Earth and Planetary Interiors, 127, 233-252.

Neiva, A.M.R., 1974. Geochemistry of tourmaline (schorlite) from granites, aplites and pegmatites from northern Portugal. Geochimica et Cosmochimica Acta 38, 1307-1317.

Oberhänsli R., Candan O., Dora, O.Ö., Dürr, S., 1997. Eclogites within the Menderes Massif crystalline complex, western Turkey, Anatolia. Lithos 41, 135-150.

Okay, A.İ., Tansel, İ., Tüysüz, O. 2001. Obduction, subduction and collision as reflected in the Upper Cretaceous-Lower Eocene sedimentary record of Western Turkey. Geological Magazine 138, 117-142.

Ota, T., Kobayashi, K., Kunihiro, T., Nakamura, E., 2008. Boron cycling by subducted lithosphere; insights from diamondiferous tourmaline from the Kokchetav ultrahigh-pressure metamorphic belt. Geochimica et Cosmochimica Acta, 72, 3531-3541.

Özer, S., Sözbilir, H., Özkar, İ., Toker, V., Sarı, B. 2001. Stratigraphy of Upper CretaceousPalaeogene sequences in the southern and eastern Menderes Massif (Western Turkey) International Journal of Earth Sciences 89, 852-866.

Palmer, M.R., 1991. Boron isotope systematics of hydrothermal fluids and tourmalines: A synthesis. Chemical Geology 94, 111-121.

Palmer, M.R., Helvac1, C., 1995. The boron isotope geochemistry of the Kirka borate deposit, western Turkey. Geochimica et Cosmochimica Acta 59, 3599-3605.

Palmer, M.R., Helvac1 C., 1997. The boron isotope geochemistry of the Neogene borate deposits of western Turkey. Geochimica et Cosmochimica Acta 61, 3161-3169. 
Palmer, M.R., Slack, J.F., 1989. Boron isotopic composition of tourmalines from massive sulfide deposits and tourmalinites. Contributions to Mineralogy and Petrology 103, 434-451.

Palmer, M.R., Swihart G.H., 1996. Boron isotope geochemistry: An overview. Reviews in Mineralogy 33, 709-744.

Palmer, M.R., Helvac1, C., Fallick A.E., 2004. Sulphur, sulphate oxygen and strontium isotopic composition of Cenozoic Turkish evaporites. Chemical Geology 209, 341-356.

Palmer, M.R., London, D., Morgan G.B., Babb, H.A., 1992. Experimental determination of fractionation of ${ }^{11} \mathrm{~B} /{ }^{10} \mathrm{~B}$ between tourmaline and aqueous vapor: A temperature- and pressure-dependent isotopic system. Chemical Geology 101, 123-130.

Peacock, S.M., Hervig, R.L., 1999. Boron isotopic composition of subduction zone metamorphic rocks. Chemical Geology, 160, 281-290.

Pe-Piper, G., Piper, D.J.W., 2001. Late Cenozoic, post-collisional Aegean igneous rocks: Nd, Pb and Sr isotopic constraints on petrogenetic and tectonic models. Geological Magazine 138, 653668.

Prelević, D., Akal, C., Foley, F., Romer, R.L., Stracke, A., van den Bogaard, P., 2012. Ultrapotassic mafic rocks as geochemical proxies for post-collisional dynamics of orogenic lithospheric mantle: The case of southwestern Anatolia, Turkey. Journal of Petrology 53, 1019-1055.

Régnier, J.L., Ring, U., Passchıer, C.W., Gessner, K., Güngör, T., 2003. Contrasting metamorphic evolution of sedimentary rocks from the Çine and Selimiye nappes in the Anatolide belt, western Turkey. Journal of Metamorphic Geology 21, 699-721.

Ribeiro da Costa, I., Mourao, C., Recio, C., Guimaraes, F., Antunes, I.M., Farinha Ramos, J., Barriga, F.J.A.S., Palmer, M.R., Milton, J.A., 2014. Tourmaline occurrences within the Penamacor-Monsanto granitic pluton and host-rocks (Central Portugal): genetic implications of crystal-chemical and isotopic features. Contributions to Mineralogy Petrology, 167, 993, doi: 10.1007/s00410-014-0993-7. 
Rimmelé, G., Oberhänsli, R., Goffe, B., Jolivet, L., Candan, O., Çetinkaplan, M., 2003. First evidence of high-pressure metamorphism in the "cover series" of the southern Menderes Massif: Tectonic and metamorphic implications for the evolution of SW Turkey. Lithos 71, $19-46$.

Rosenberg, P.E., Foit, F.F., Jr., 1979. Synthesis and characterization of alkali-free tourmaline. American Mineralogists 64, 180-186.

Satır, M., Friedrichsen, H., 1986. The origin and evolution of the Menderes Massif, Turkey: A rubidium/strontium and oxygen isotope study. Geologisches Rundschau 75, 703-714.

Scambelluri, M., Tonarini, S. 2012. Boron isotope evidence for shallow fl uid transfer across subduction zones by serpentinized mantle. Geology, 40, 10, 907-910.

Shaw, D.R., Hodgson, C.J., Leitch, C.H.B., Turner, R.J.W., 1993. Geochemistry of tourmaline, muscovite, and chlorite-garnet-biotite alteration, Sullivan $\mathrm{Zn}-\mathrm{Pb}$ deposit, British Columbia. Geological Survey of Canada Current Research Paper 93-1A, 97-107.

Sherlock, S., Kelley, S.P., Inger, S., Harris N., Okay, A.I., 1999. ${ }^{40} \mathrm{Ar}-{ }^{39} \mathrm{Ar}$ and Rb-Sr geochronology of high-pressure metamorphism and exhumation history of the Tavsanli Zone, NW Turkey. Contributions to Mineralogy and Petrology, 137, 46-58.

Slack J.F., Palmer, M.R., Stevens B.P.J., 1989. Boron isotope evidence for the involvement of nonmarine evaporites in the origin of the Broken Hill ore deposits. Nature 342, 913-916.

Slack, J.F., Palmer, M.R., Stevens, B.P.J., Barnes, R.G., 1993. Origin and significance of tourmalinerich rocks in the Broken Hill district, Australia. Economic Geology 88, 505-541.

Slack, J.F., Stevens, B.P.J., 1994. Clastic metasediments of the Early Proterozoic Broken Hill Group, New South Wales, Australia: Geochemistry, provenance, and metallogenic significance. Geochimica et Cosmochimica Acta 58, 3633-3652.

Slack, J.F., 1996. Tourmaline associations with hydrothermal ore deposits. Reviews in Mineralogy 33, 559-643. 
Smith, H.J., Leeman, W.P., Davidson, J., Spivack, A.J., 1997. The B isotopic composition of arc lavas from Martinique, Lesser Antilles. Earth and Planetary Science Letters, 146, 303-314.

Smith, H.J., Spivack, A.J., Staudigel, H., Hart, S.R., 1995. The boron isotopic composition of altered oceanic crust. Chemical Geology, 126, 119-135.

Spivack, A.J., Edmond, J.M., 1987. Boron isotope exchange between seawater and the oceanic crust. Geochimica et Cosmochimica Acta, 51, 1033-1043.

Straub, S.M., Layne, G.D., 2002. The systematics of boron isotopes in Izu arc front volcanic rocks. Earth and Planetary Science Letters, 198, 26-39.

Swihart, G.H., Moore, P.B., 1989. A reconnaissance of the boron isotopic composition of tourmaline. Geochimica et Cosmochimica Acta, 53, 911-916.

Şengör, A.M.C., Y1lmaz, Y., 1981. Tethyan evolution of Turkey: A plate tectonic approach. Tectonophysics 75, 181-241.

Şengör, A.M.C., Satır, M., Akkök, R., 1984. Timing of tectonic events in the Menderes Massif western Turkey: Implications for tectonic evolution and evidence for Pan-African basement in Turkey. Tectonics 3, 693-707.

Taylor, S.R., McLennan, S.M. 1985. The Continental Crust: Its Composition and Evolution. Blackwell, Oxford. 312 pp.

Tonarini, S., Leeman, W.P., Ferrara, G., 2001. Boron isotopic variations in lavas of the Aeolian volcanic arc, South Italy. Journal of Volcanology and Geothermal Research, 110, 155-170.

Trotet, F., Jolivet, L. \& Vidal, O. 2001. Tectono-metamorphic evolution of Syros and Sifnos islands (Cyclades, Greece). Tectonophysics 338, 179-206.

van Hinsberg, V.J., Henry, D.J., Dutrow, B.L., 2011. Tourmaline as a petrologic forensic mineral: A unique recorder of its geologic past. Elements 7, 323-332. 
van Hinsbergen, D.J.J., Kaymakçı, N., Spakman, W., Torsvik, T.H., 2010. Reconciling the geological history of western Turkey with plate circuits and mantle tomography. Earth and Planetary Science Letters 297, 674-686.

Whitney, D.L., Bozkurt, E., 2002. Metamorphic history of the southern Menderes Massif, western Turkey. Geological Society of America Bulletin 114, 829-838.

Whitney, D.L., Teyssier, C., Kruckenberg, S.C., Morgan, V.L., Iredale, L.J. 2008. High-pressurelow-temperature metamorphism of metasedimentary rocks, southern Menderes Massif, western Turkey. Lithos 101, 218-232.

Zheng, Y.F. 1993. Calculation of oxygen isotope fractionation in hydroxyl-bearing silicates. Earth and Planetary Science Letters 120, 247-263. 


\section{Figure Captions}

Figure 1. General geological map of the central and southern part of the Menderes Massif, including tourmaline sample localities.

Figure 2. Outcrops of tourmaline-rich rocks in the Menderes Massif. a) Laminated structure of bedded tourmalinite with irregular quartz veinlets in the Karahayıt region, b, c) Folded tourmalinite associated with crenulated tourmaline-bearing pelitic metasediments from the Karahayıt region. d) Local tourmaline-rich rip-up clasts in the Karahayıt region. (e-f) Yeşilköy; (g-h) Ödemiş-Bozcayaka; (i-m) Aydın-Koçarlı (Çulhalar); (n-o) Tourmaline nodules within gneiss in the Irmadan region; (p-r) anhedral to subhedral tourmaline crystals occur locally within strongly sheared granitic gneiss near Eskihisar (AydınSultanhisar) Aydın-Eskihisar (Salavatli); (s-v) Labranda.

Figure 3. Photomicrographs of tourmalinite from the Karahayit area. a) tourmalines with optical zoning (parallel nicol), b) subhedral garnet minerals with quartz and tourmaline inclusions (cross nicol), c) syntectonic rotation of tourmalinite pebble which formed before tectonism (cross nicol). (Tr: tourmaline, Qtz: quartz, Gr: garnet). Photomicrographs of tourmalinite from the Yeşilköy area. d) Fine-grained quartz and tourmaline rock (parallel nicol), e) tourmalines with optical zoning (parallel nicol), f) euhedral garnet minerals with quartz and tourmaline inclusions (cross nicol), g) syntectonic rotation of garnet (parallel nicol). (Tr: tourmaline, Qtz: quartz, Gr: garnet). Photomicrographs of tourmaline from the Bozcayaka area; (h-i) medium-grained anhedral tourmalines within gneiss. (j) Coarsegrained tourmaline within the paragneiss in the Irmadan region. (k) Subhedral tourmaline crystal within strongly sheared granitic gneiss in the Salavatlı region.

Figure 4. Comparison of $\delta^{11} \mathrm{~B}$ values derived from two separate days (open squares and crosses) of LA-MC-ICP-MS analyses of tourmalines previously analysed by TIMS (Palmer \& Slack, 1989). The dashed line is the 1:1 correlation between the two methods.

Figure 5. Plot of $\mathrm{Fe} /(\mathrm{Fe}+\mathrm{Mg})$ versus $\mathrm{Na} /(\mathrm{Na}+\mathrm{Ca})$ in atoms per formula unit.

Figure 6. a) $\mathrm{Al}-\mathrm{Fe}($ tot)- $\mathrm{Mg}$ and b) $\mathrm{Ca}-\mathrm{Fe}($ tot)-Mg ternary diagrams (after Henry \& Guidotti, 1985) for tourmalines from Menderes Massif (see Figure 4 for key to symbols). TS=Taylor and Slack (1984), P=Plimer (1988). (1) Li-rich granitic rocks, pegmatites and aplites, (2) Lipoor granitic rocks, pegmatites and aplites, (3) hydrothermally altered granitic rocks, (4) metapelites and metapsammites co-existing with Al-saturating phase, (5) metapelites and 
metapsammites not co-existing with Al-saturating phase, (6) $\mathrm{Fe}^{3+}$-rich quartz-tourmaline rocks, calc-silicate rocks and metapelites, (7) Ca-rich metapelites, (8) Ca-poor metapelites, metapsammites and quartz-tourmaline rocks.

Figure 7. Plot of $\mathrm{Al}$ versus $(\mathrm{Fe}+\mathrm{Mg}+\mathrm{Mn}+\mathrm{Ti})$ in atoms per formula unit.

Figure 8. (a) $\mathrm{Mg}$ vs. Fe (total) diagram for tourmaline found in metasediments, gneiss and tourmalinites from the Menderes Massif, western Anatolia. The dashed and dotted lines represent joins between selected end members. The array of data is generally along the schorl-dravite join and is most consistent with operation of the $\mathrm{MgFe}^{2+}{ }_{-1}$ substitution (b) $\mathrm{Al}$ (total) vs. $\mathrm{Fe}$ (total) in tourmaline found in metasediments, gneiss and tourmalinites from the Menderes Massif, western Anatolia.. The data are classified as schorl-dravite end-members.

Figure 9. Histogram of $\delta^{11} \mathrm{~B}$ values measured in tourmaline samples from tourmalinites, metasediments and gneisses from Menderes Massif in comparison with other tourmalines and some important geochemical reservoirs. Arrows mark zoned grains pointing from core to rim compositions. The boxes represent the total range of all analysed samples. Data sources: ${ }^{1}$ Chaussidon \& Albaréde (1992); ${ }^{2}$ Kasemann et al. (2000); ${ }^{3}$ Chaussidon \& Jambon (1994); ${ }^{4}$ le Roux et al. (2004); ${ }^{5}$ Spivack \& Edmont (1987); ${ }^{6}$ Chaussidon \& Marty (1995); ${ }^{7}$ Ishikawa \& Nakamura (1992); ${ }^{8}$ Smith et al. (1995); ${ }^{9}$ Barth (1993); ${ }^{10}$ Marschall et al. (2008); ${ }^{11}$ Marschall et al. (2006); ${ }^{12}$ Altherr et al. (2004); ${ }^{13}$ Marschall et al. (2009); ${ }^{14}$ Ota et al. (2008); ${ }^{15}$ Nakano \& Nakamura (2001); ${ }^{16}$ Bebout \& Nakamura (2003); ${ }^{17}$ Palmer \& Slack (1989); ${ }^{18}$ Swihart \& Moore (1989); ${ }^{19}$ Palmer \& Swihart (1996); ${ }^{20}$ Marschall \& Ludwig (2006); ${ }^{21}$ Ishikawa \& Nakamura (1994); ${ }^{22}$ Ishikawa \& Tera (1997); ${ }^{23}$ Smith et al. (1997); ${ }^{24}$ Tonarini et al. (2001); ${ }^{25}$ Clift et al. (2001); ${ }^{26}$ Ishikawa et al. (2001); ${ }^{27}$ Straub \& Layne (2002); ${ }^{28}$ Peacock \& Hervig (1999); ${ }^{29}$ Benton et al. (2001); ${ }^{30}$ this study.

Figure 10. Chondrite-normalized (Taylor and McLennan, 1985) rare earth element patterns of tourmalinites (solid lines) and gneisses and metasediments (dashed lines) of tourmalinebearing rocks from the Menderes Massif. (A) Karahayıt, (B) Yeşilköy, (C) Irmadan, (D) Labraunda, (E) Madran and Bafa, (F) Çine.

Figure 11. Chemical composition and boron isotope composition of tourmalinite-bearing rocks (open circles) and gneisses and metasediments (crosses) from the Menderes Massif. The solid horizontal lines (and associated numerical values) indicate the average y-axis values, 
with the dotted lines marking the 2SE ranges of the average values of the two groups of rocks. (A) $\mathrm{Nb} / \mathrm{Al}_{2} \mathrm{O}_{3}$, (B) $\mathrm{K}_{2} \mathrm{O} / \mathrm{Al}_{2} \mathrm{O}_{3}$, (C) $\mathrm{MgO} / \mathrm{Al}_{2} \mathrm{O}_{3}$, (D) $\mathrm{Eu}$ anomaly, Eu* defined as $\mathrm{Eu}_{\mathrm{N}} /\left[\left(\mathrm{Sm}_{\mathrm{N}}\right)\left(\mathrm{Gd}_{\mathrm{N}}\right)^{0.5}\right]$ (Taylor and McLennan, 1985).

Figure 12. Variations in $\delta^{11} \mathrm{~B}$ values of the tourmalines vs. their $\mathrm{Fe} /(\mathrm{Fe}+\mathrm{Mg})$ and $\mathrm{Na} /(\mathrm{Na}+\mathrm{Ca})$ ratios.

Figure 13. Schematic cross-section showing internal imbrication and partial subduction of the Menderes Massif (adapted from Rimmelé et al. 2003). MM: Menderes Massif; LN: Liycian Nappes; BFZ: Bornova Flysch Zone; CC: Cycladic Complex; İSZ: İzmir-Ankara Zone 


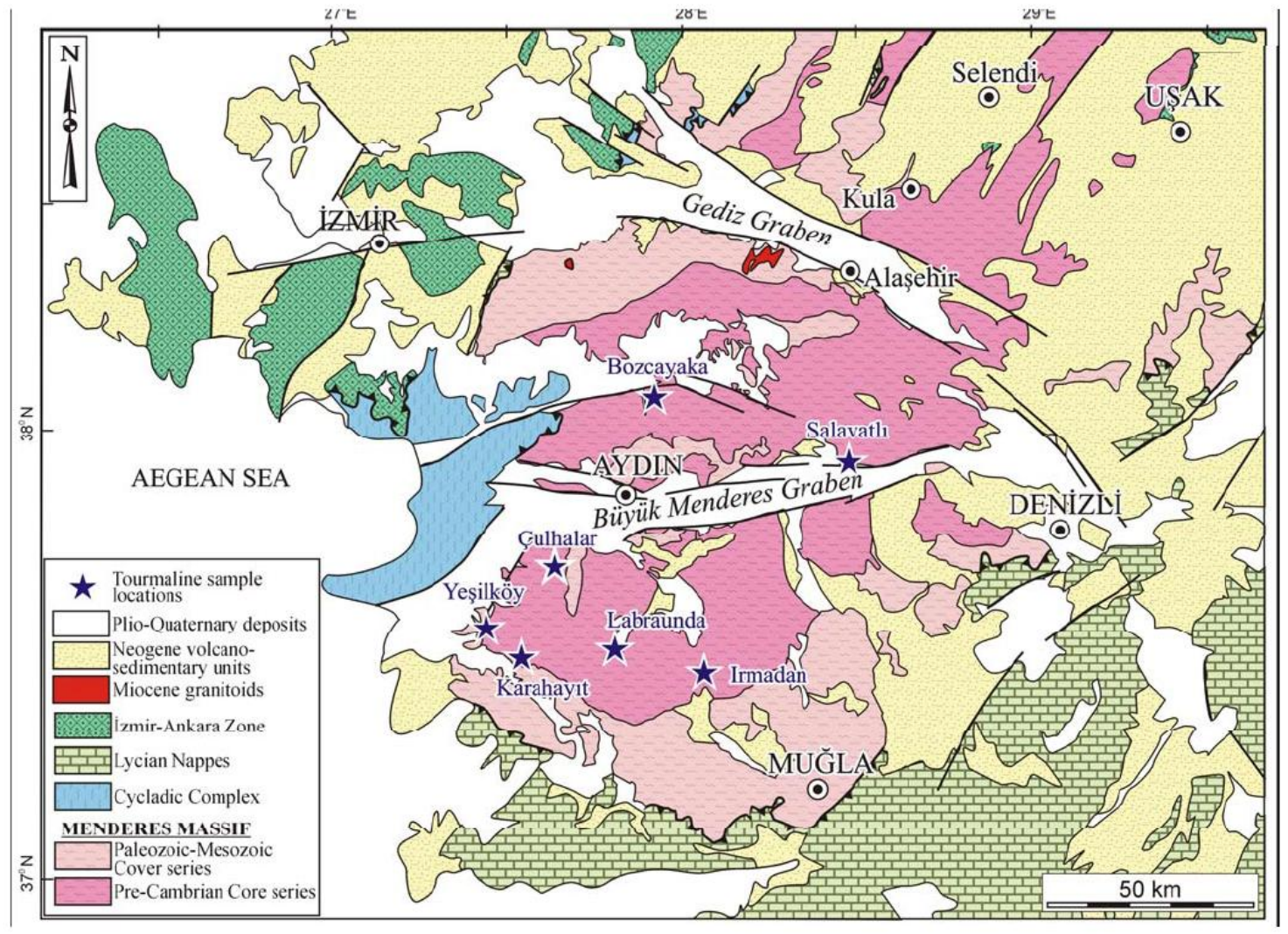

Figure 1 

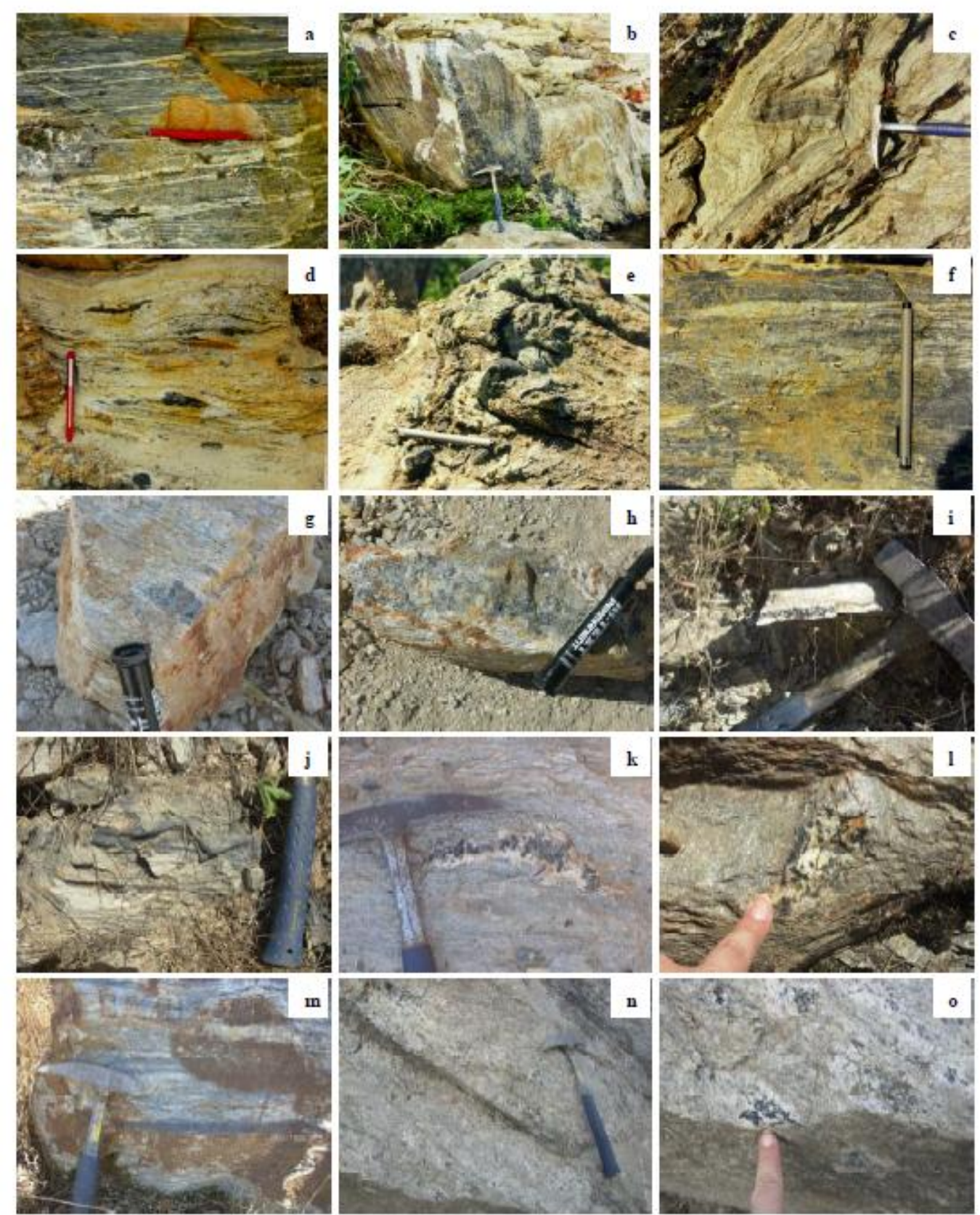

Figure 2. 

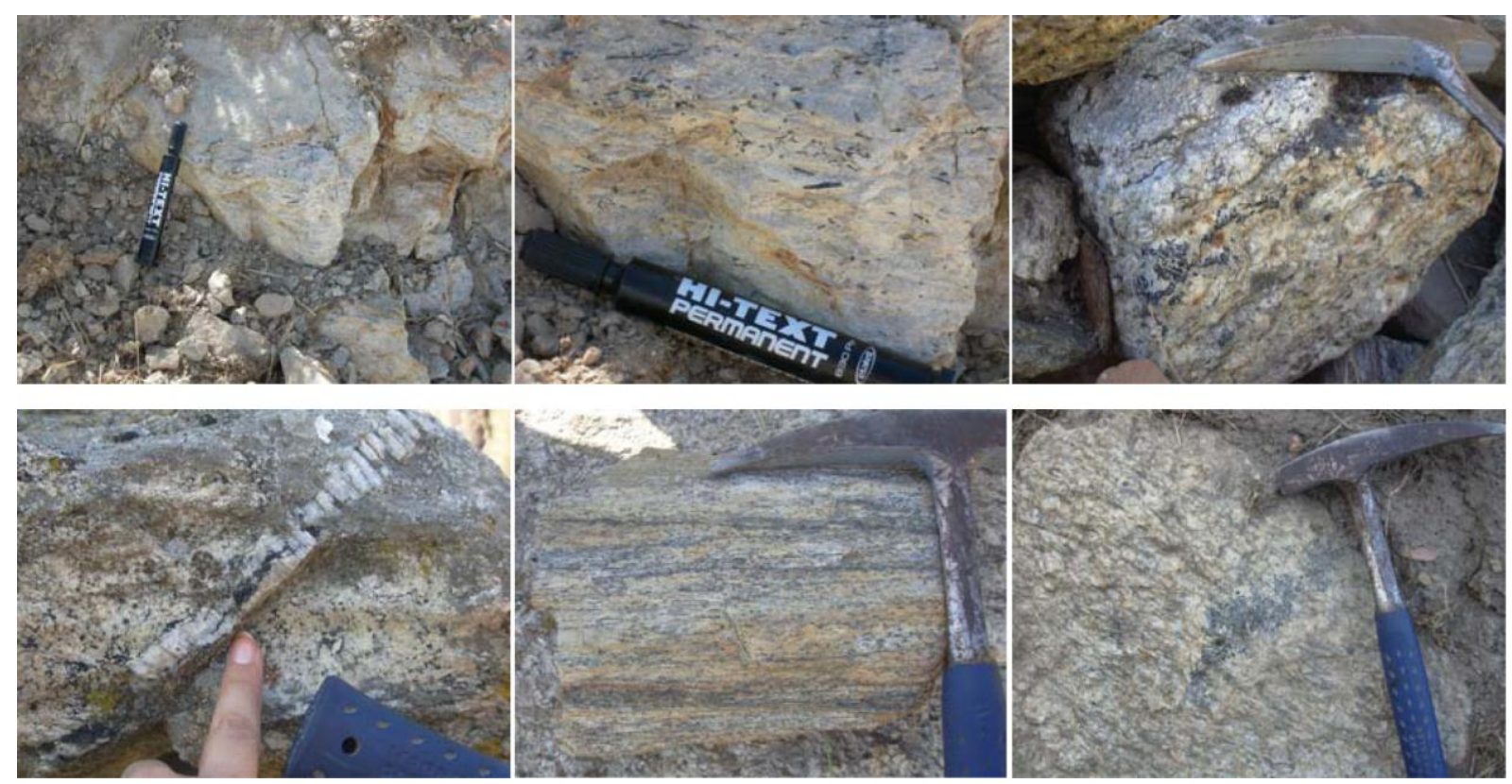


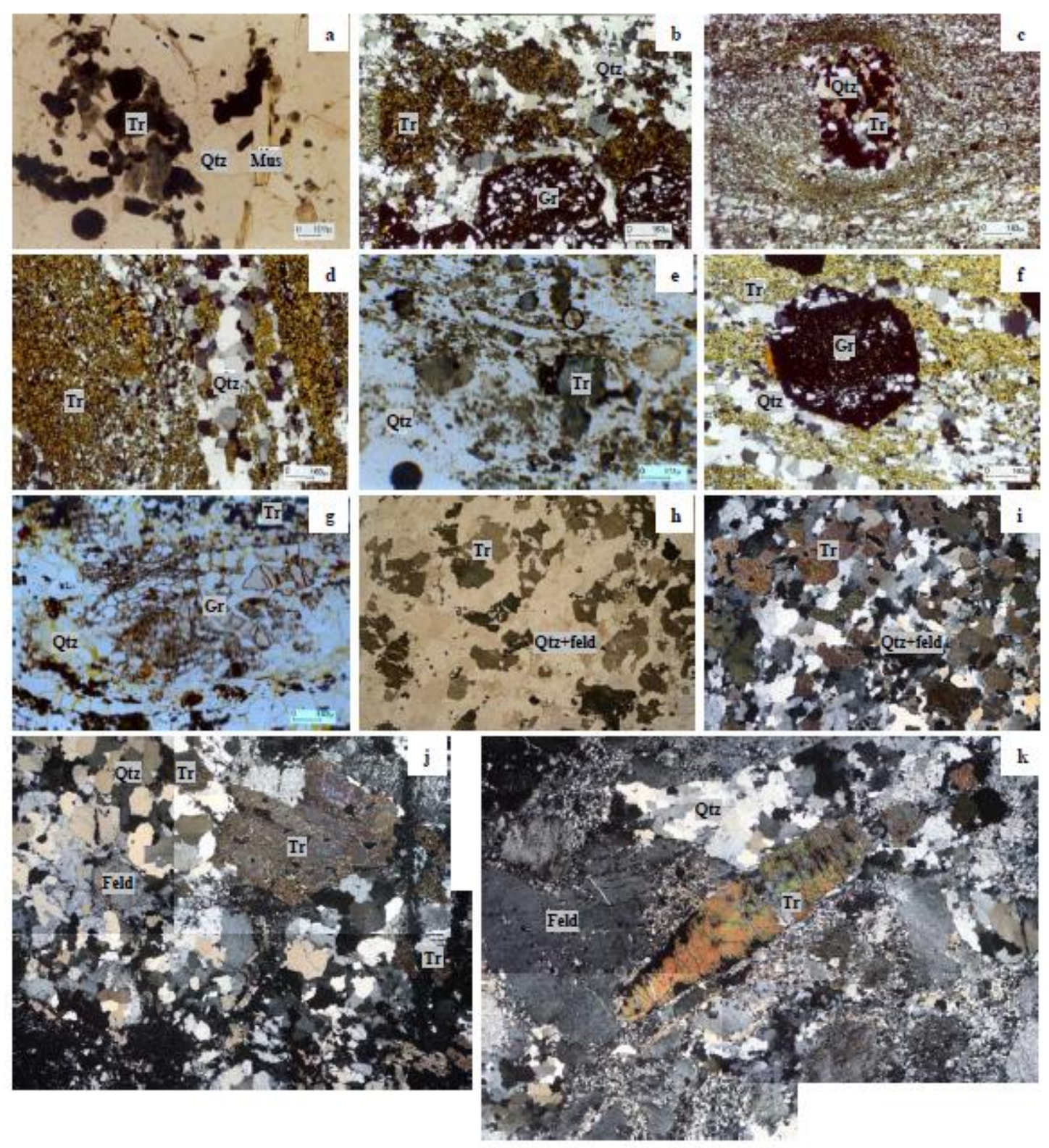

Figure 3 


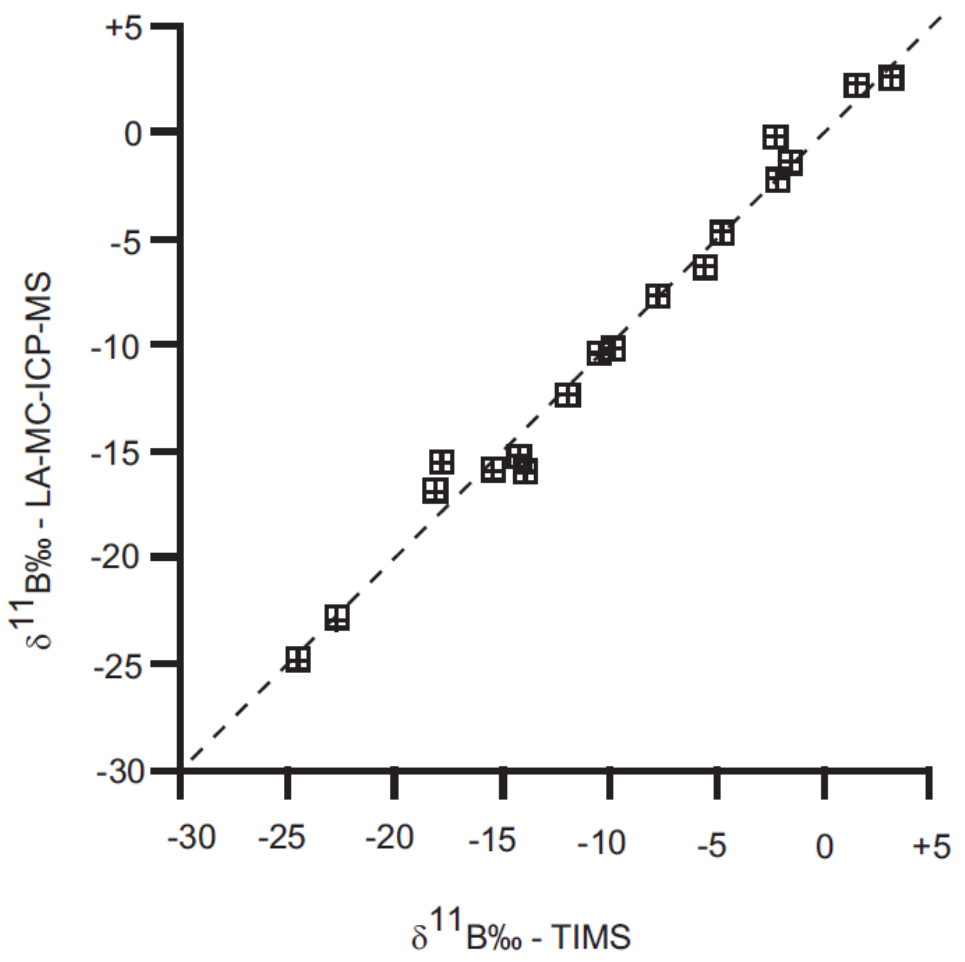

Figure 4 


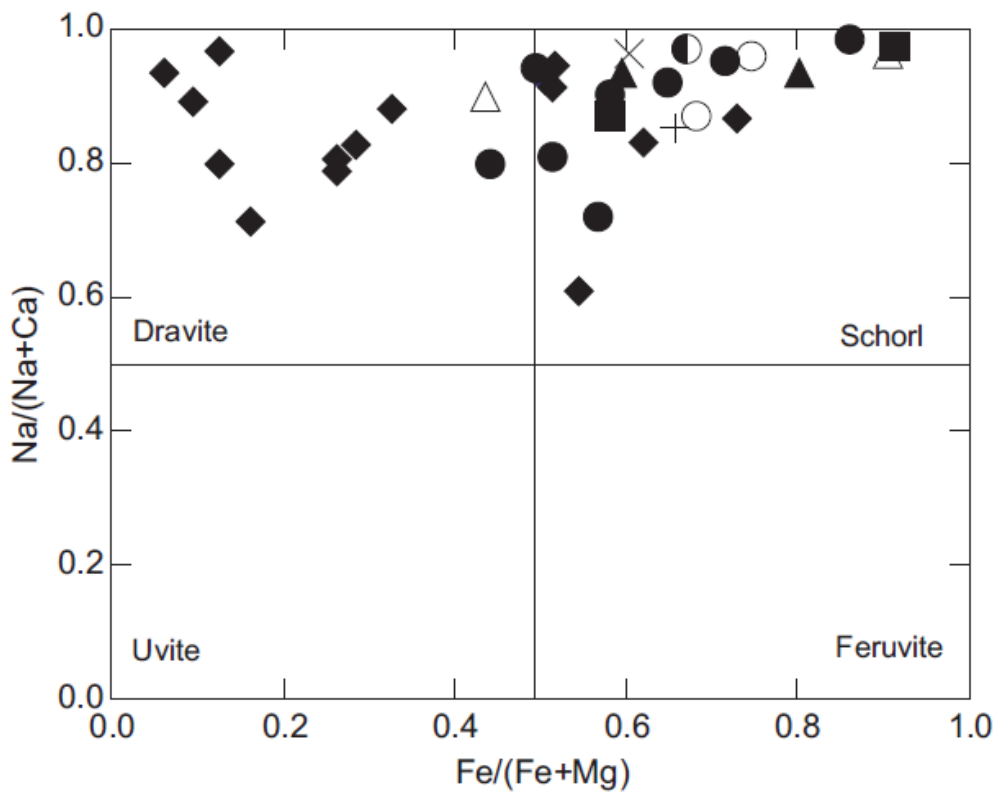

$\boldsymbol{\nabla}=$ Karahayıt tourmalinites

= Yeşilköy tourmalinites

$\boldsymbol{\Delta}$ = samples from gneiss and pegmatite near Sultanhisar Salavatlı area, active geothermal system

= tourmalines from Labraunda region

$\triangle$ = samples of tourmaline nodules from granite contact zone at the Irmadan area

$\mathrm{O}=$ contact metasomatic occurrences from Aydın-Çulhalar region

$+=$ nodular samples within the allocthon gneiss from Bozcayaka region

$X=$ tourmaline samples within the albite, amphibolite, garnet schist from Ovacık Yaylası

$\hat{s}=$ tourmaline sample within the granite from Gökçay stream

Figure 5 


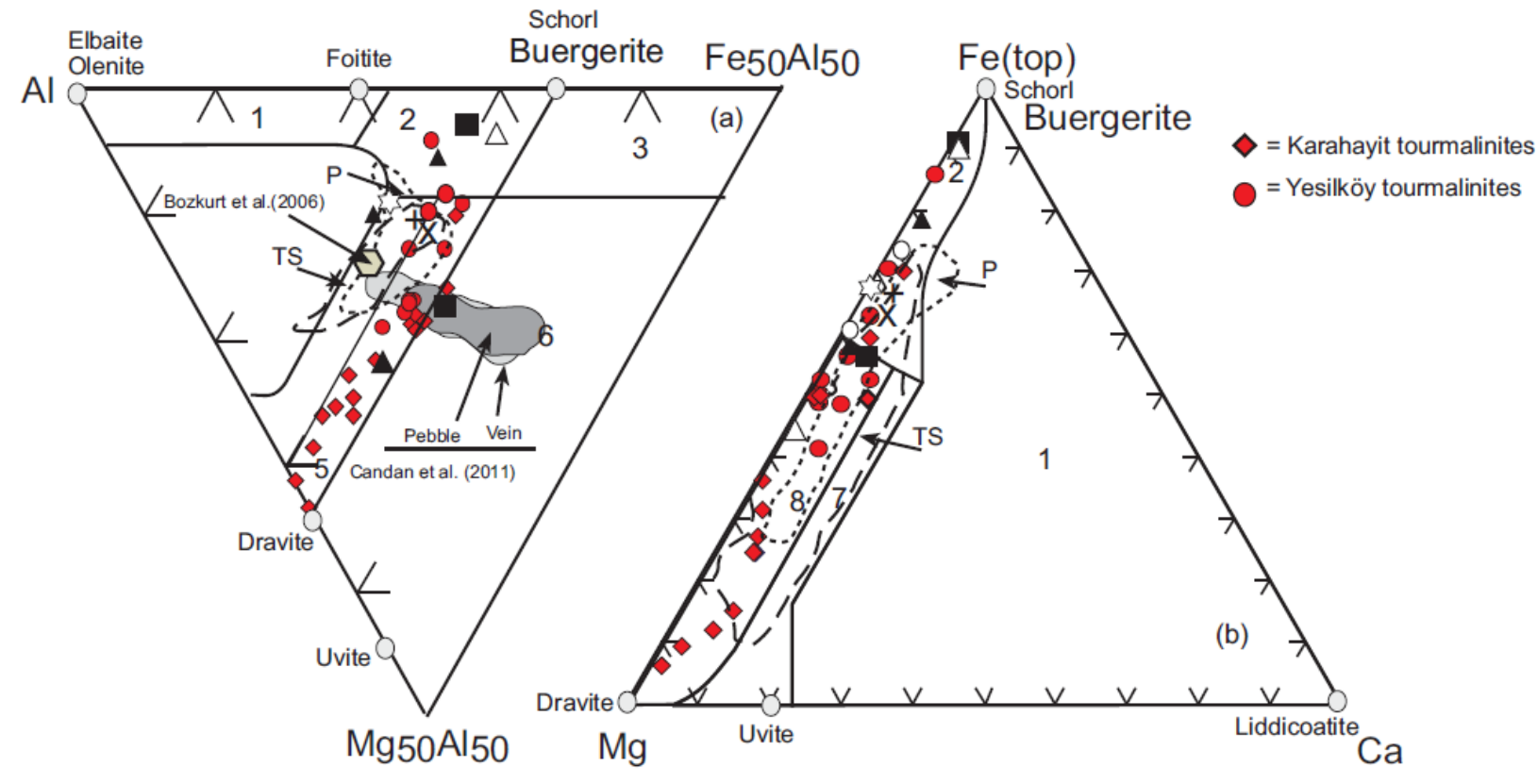

Figure 6 


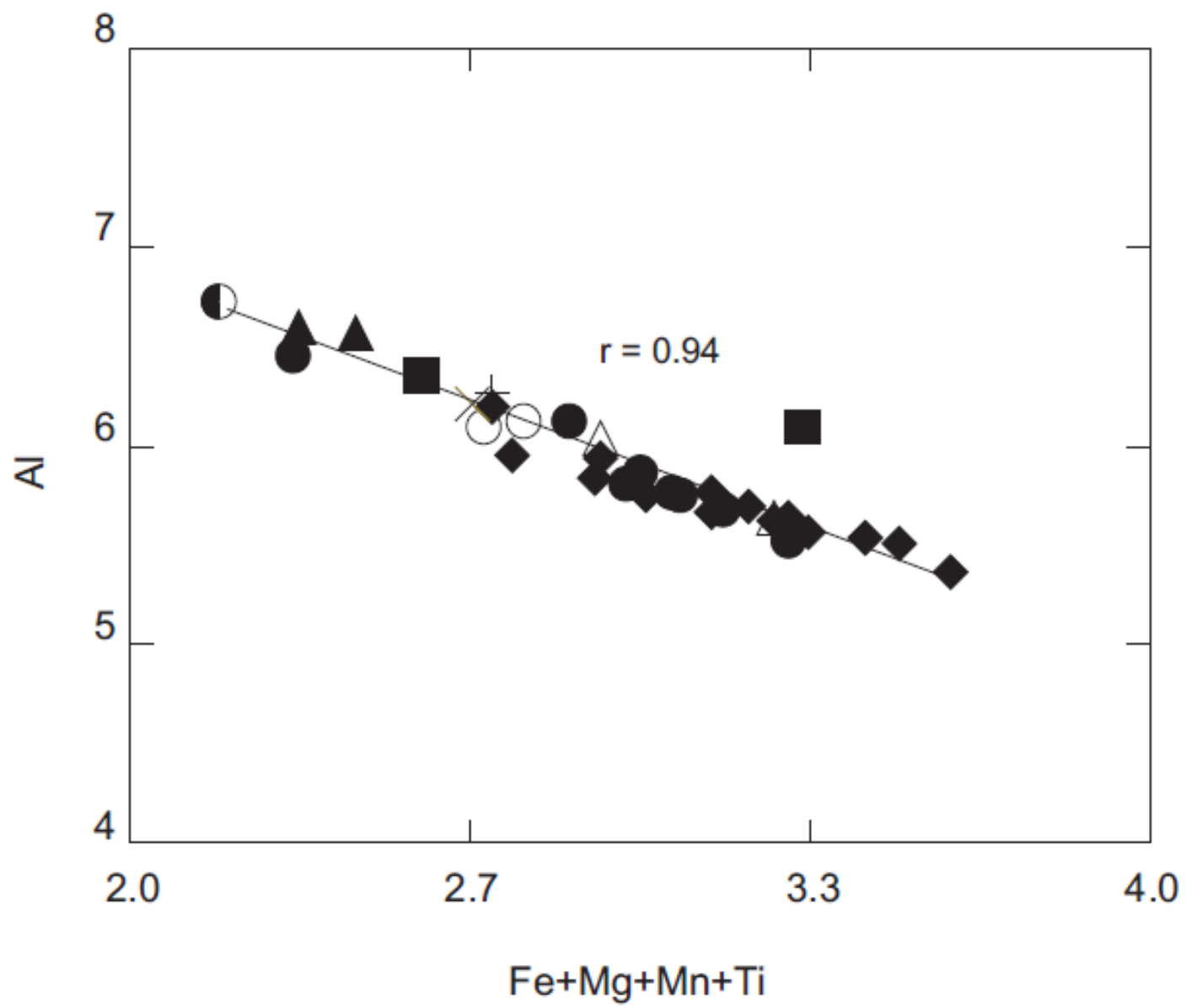

Figure 7 

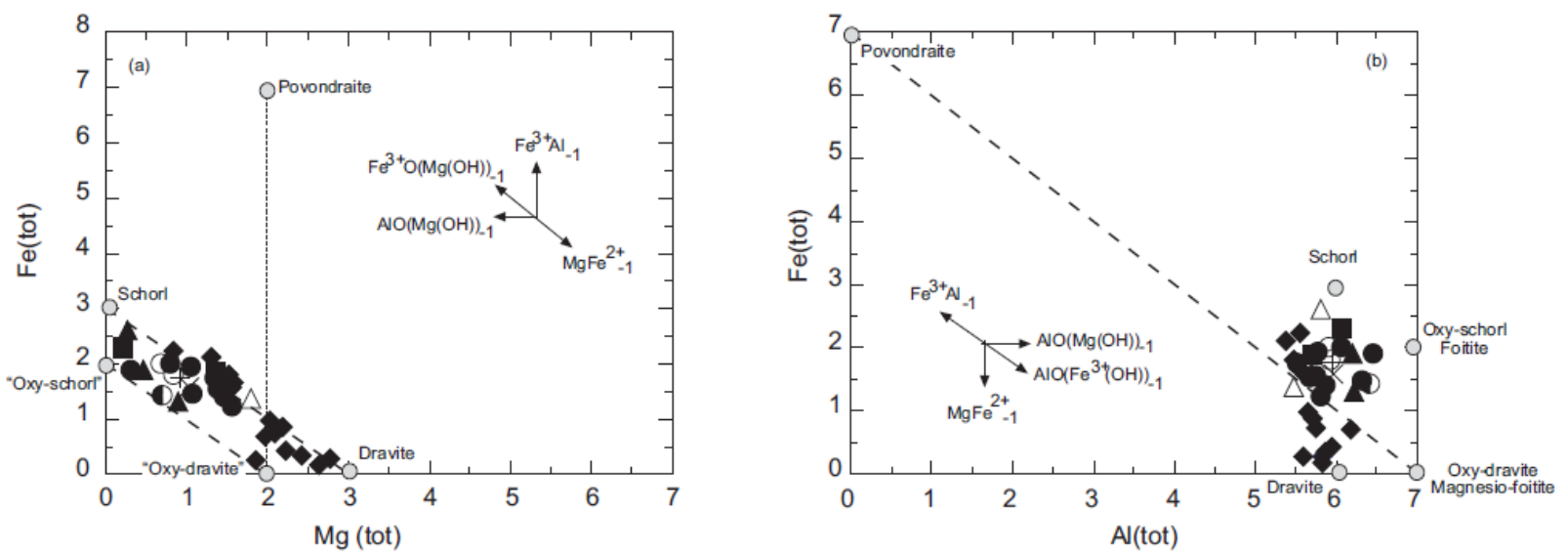

Figure 8 


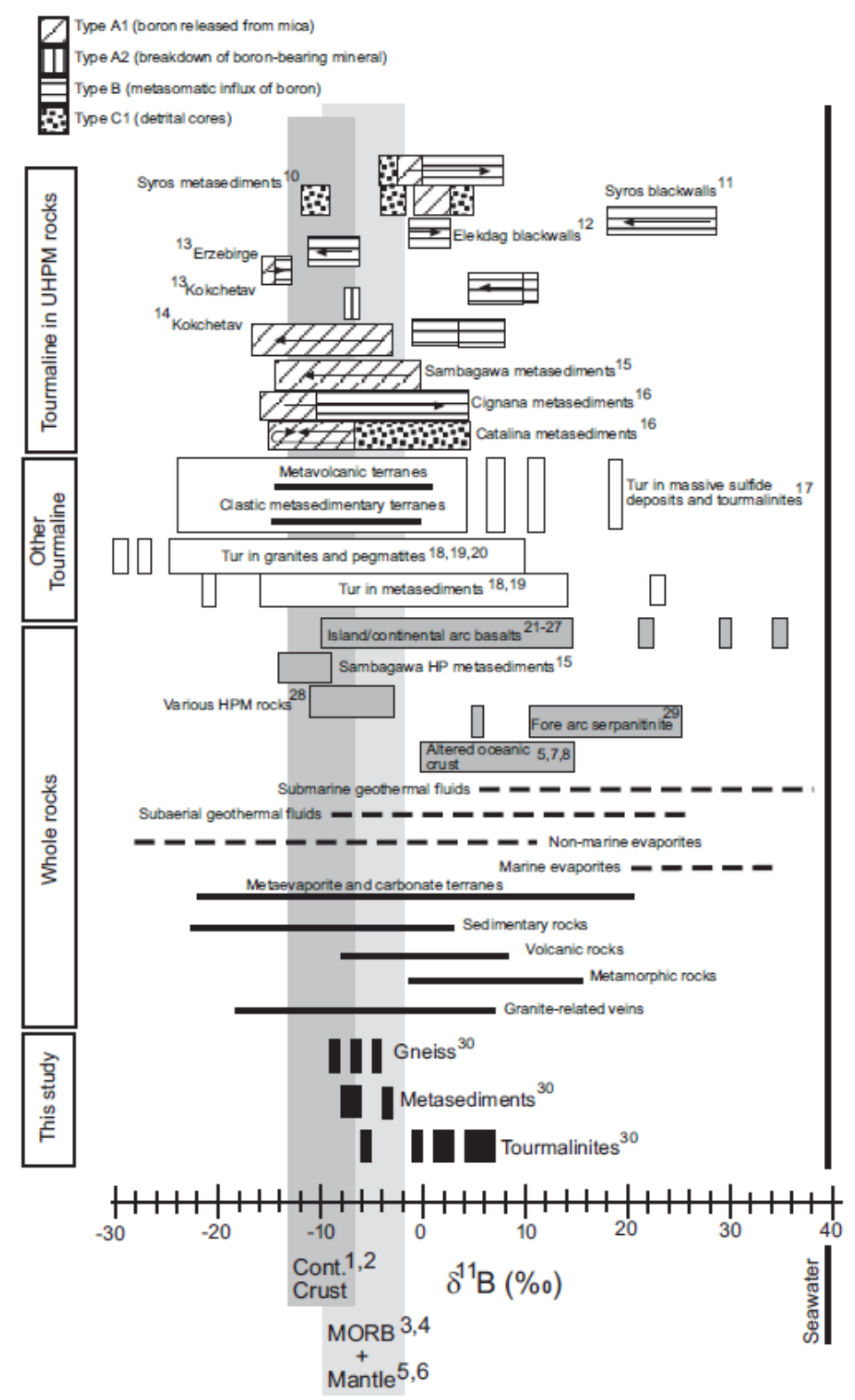

Figure 9 


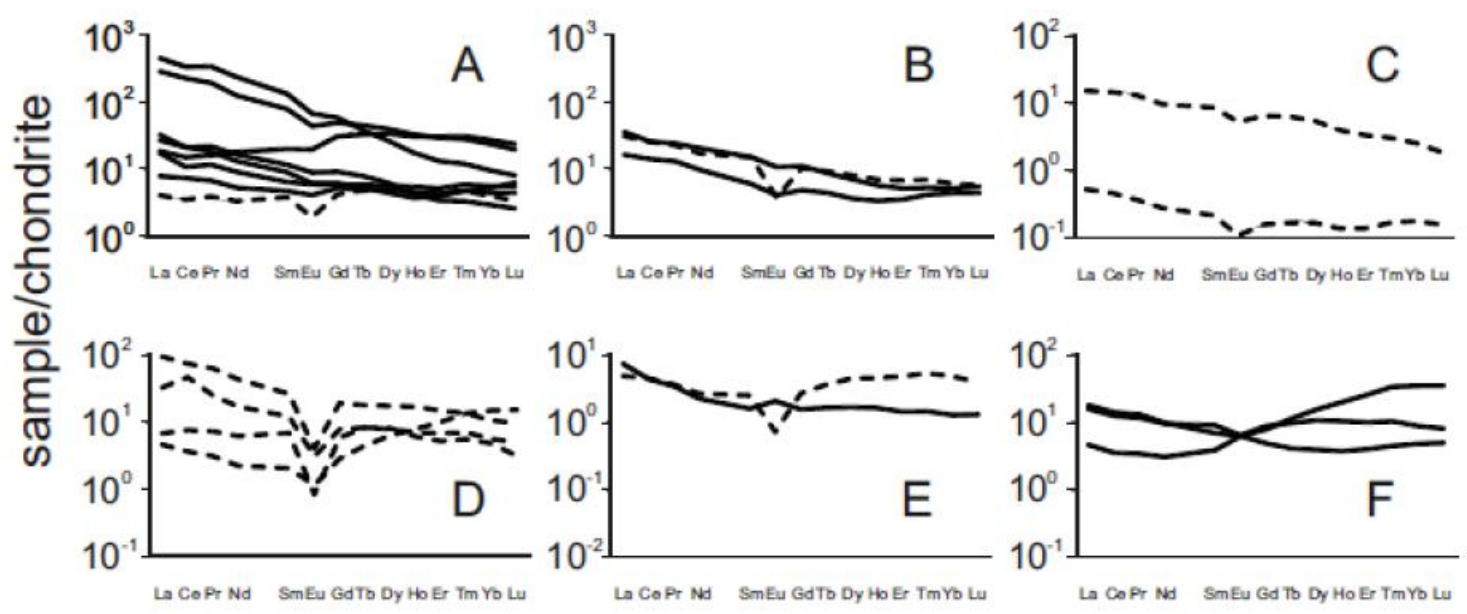

Figure 10 

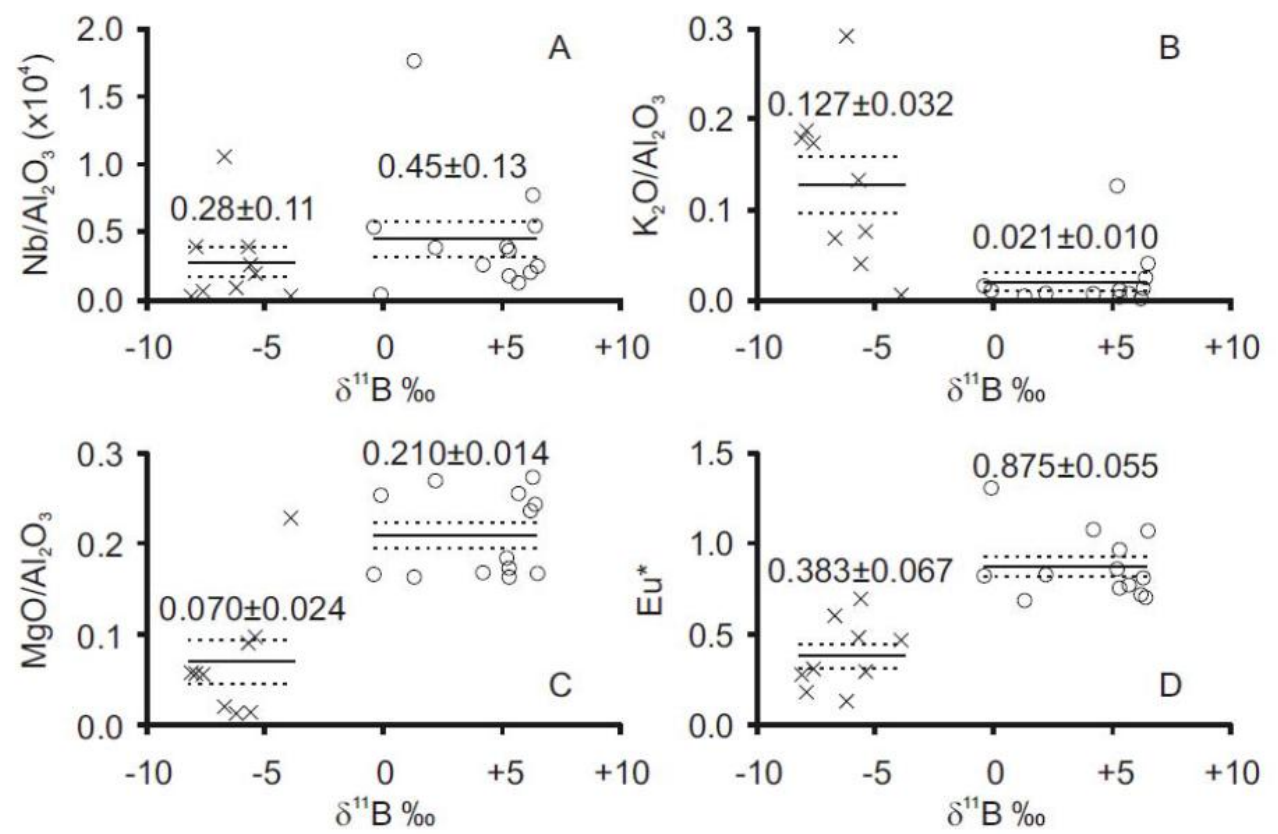

Figure 11 

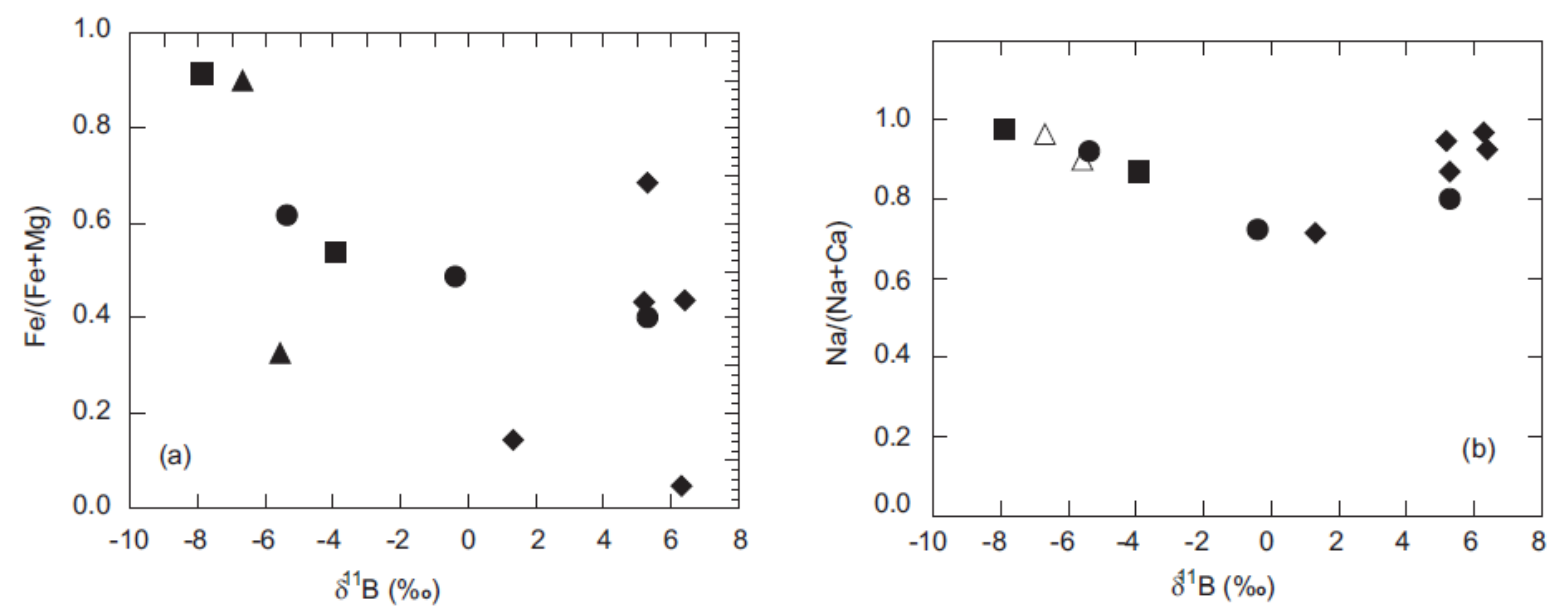

Figure 12 


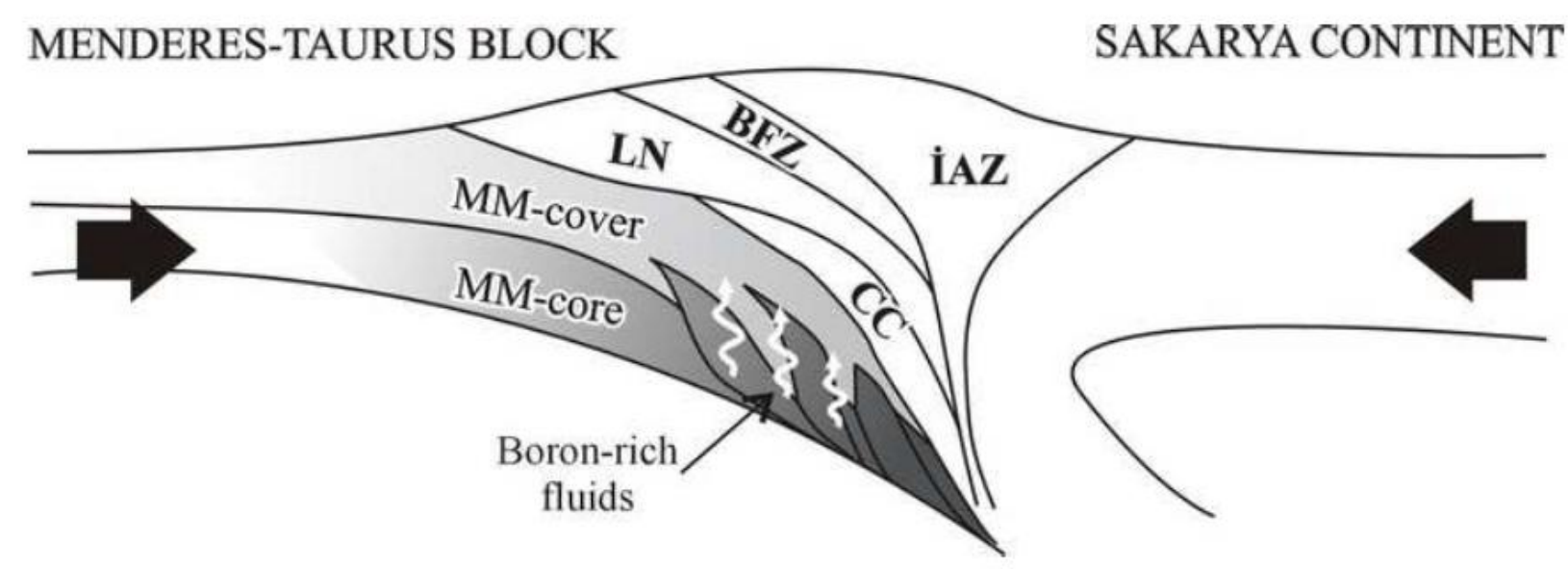

Figure 13 
Table 1. Classification and characteristics of Menderes Massif tourmaline samples.

\begin{tabular}{ccccc}
\hline Type Location Sample Numbers & Most Rock & Grain & \\
& & & \\
& & & \\
& &
\end{tabular}

74

$75 / \mathrm{C}$

I Karahayit $\quad 75 / \mathrm{D} 1$

76

78

Granoblastic

78/F Tourmalinites

Qtz, Ms, Bt, < 0.1 texture, anhedral Grt, Zrn, Ap $\mathrm{mm} \quad$ to subhedral

$82 / 2$

Yeşilköy

$82 / 3$

Madran

58

27

Çine $\quad 01-136 / 2$

01-139

4

Metasediment- Qtz, Ms, Bt, < 800 Anhedral to

II Labraunda

64

hosted

Rt, Grt, Zrn $\quad \mu \mathrm{m} \quad$ subhedral crystals 
69

70

Karahayıt

72

I-1

III Irmadan

I-3

Bafa

BS-1

Yeşilköy tourmalines

Anhedral

to

subhedral

crystals, eyeshaped nodules

${ }^{*} \mathrm{Qtz}=$ quartz, Ms=muscovite, Bt=biotite, Grt=garnet, Zrn=zircon, Ap=apatite, Rt=rutile, Kfs=Kfeldispar. 
Table 2. Microprobe analyses of tourmaline crystals from the Menderes Massif. Turkey.

\begin{tabular}{|c|c|c|c|c|c|c|c|c|c|c|c|c|c|c|c|c|c|}
\hline \multicolumn{5}{|c|}{ Karahayit } & \multicolumn{3}{|c|}{ Labraunda } & \multirow[t]{2}{*}{ Gökçay } & Irmadan & Salavatli & \multirow[t]{2}{*}{ Ovacık } & \multirow[t]{2}{*}{ Bozcakaya } & \multirow[t]{2}{*}{ Çulhalar } & \multicolumn{4}{|c|}{ Yeşilköy } \\
\hline $71 \mathrm{~A}-$ & & & 77A- & 77A- & & & & & & & & & & TY- & TY- & TY- & \\
\hline 33 & $10-40$ & $10-02$ & 14 & 22 & $10-04$ & L-JA & L- & $u-1$ & 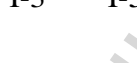 & $1-2$ & $110-5$ & $110-00$ & 1110-100 & 03 & 04 & 05 & 10 \\
\hline
\end{tabular}

\begin{tabular}{|c|c|c|c|c|c|c|c|c|c|c|c|c|c|c|c|c|}
\hline $\mathrm{SiO}_{2}$ & 35.91 & 38.16 & 36.84 & 37.20 & 36.23 & 34.88 & 34.87 & 33.85 & 34.97 & 33.94 & 35.55 & 33.72 & 34.48 & 35.35 & 33.24 & 35.58 \\
\hline $\mathrm{Al}_{2} \mathrm{O}_{3}$ & 28.34 & 31.71 & 30.08 & 31.61 & 30.00 & 27.30 & 32.16 & 31.96 & & 30.16 & 29.10 & 33.38 & 34.38 & 32.32 & 31.06 & 31.48 \\
\hline $\mathrm{TiO}_{2}$ & 0.89 & 0.68 & 0.74 & 0.74 & 0.56 & 1.98 & 0.70 & 0.40 & & 0.28 & 0.73 & 0.45 & 1.07 & 0.41 & 0.30 & 0.37 \\
\hline $\mathrm{FeO}$ & 11.31 & 3.20 & 7.76 & 2.66 & 6.30 & 15.46 & 13.98 & & 10.52 & 18.35 & 10.09 & 13.67 & 9.60 & 11.59 & 12.20 & 13.17 \\
\hline $\mathrm{MnO}$ & 0.03 & 0.10 & 0.06 & 0.13 & 0.10 & 0.04 & 0.00 & 0.00 & 0.20 & 0.00 & 0.00 & 0.00 & 0.00 & 0.00 & 0.00 & 0.00 \\
\hline $\mathrm{MgO}$ & 6.22 & 9.41 & 7.59 & 10.17 & 8.96 & 3.24 & 4.42 & 0.88 & 2.90 & 1.07 & 7.32 & 1.89 & 3.69 & 4.29 & 3.60 & 3.43 \\
\hline $\mathrm{CaO}$ & 0.39 & 1.28 & 0.19 & 1.10 & 1.00 & 0.67 & 0.67 & 0.13 & 0.11 & 0.17 & 0.51 & 0.31 & 0.28 & 0.17 & 0.72 & 0.61 \\
\hline $\mathrm{Na}_{2} \mathrm{O}$ & 2.61 & 1.78 & 2.94 & 2.46 & 2.41 & 2.36 & 2.56 & 2.50 & 1.98 & 2.52 & 2.50 & 2.25 & 2.27 & 2.58 & 2.25 & 2.31 \\
\hline $\mathrm{K}_{2} \mathrm{O}$ & 0.04 & 0.04 & 0.02 & 0.02 & 0.03 & 0.06 & 0.00 & 0.00 & 0.00 & 0.00 & 0.00 & 0.00 & 0.00 & 0.00 & 0.00 & 0.00 \\
\hline
\end{tabular}




\begin{tabular}{|c|c|c|c|c|c|c|c|c|c|c|c|c|c|c|c|c|c|c|c|c|}
\hline $\mathrm{Si}(4)$ & 6.00 & 6.00 & 6.00 & 5.94 & 5.95 & 6.00 & 5.61 & 5.71 & 5.70 & 5.77 & 5.84 & 5.62 & 5.61 & 5.76 & 5.68 & 5.83 & 6.00 & 6.00 & 6.00 & 5.95 \\
\hline $\mathrm{Al}(4)$ & 0.00 & 0.00 & 0.00 & 0.06 & 0.05 & 0.00 & 0.39 & 0.29 & 0.30 & 0.23 & 0.15 & 0.38 & & 0.24 & 0.32 & 0.17 & 0.00 & 0.00 & 0.00 & 0.05 \\
\hline $\mathrm{Al}(\mathrm{z})$ & 5.62 & 5.95 & 5.82 & 5.87 & 5.72 & 5.56 & 5.71 & 6.00 & 6.00 & 5.81 & 5.48 & 6.00 & 6.00 & 5.97 & 5.94 & 5.92 & 5.52 & 5.81 & 5.76 & 6.00 \\
\hline $\mathrm{Fe}(\mathrm{z})$ & 0.38 & 0.05 & 0.18 & 0.13 & 0.28 & 0.44 & 0.29 & 0.00 & 0.00 & 0.19 & 0.51 & & 0.00 & 0.03 & 0.06 & 0.08 & 0.48 & 0.19 & 0.24 & 0.00 \\
\hline $\mathrm{Al}(\mathrm{y})$ & 0.00 & 0.00 & 0.00 & 0.00 & 0.00 & 0.00 & 0.00 & 0.06 & 0.42 & 0.00 & 0.00 & 0.19 & 0.21 & 0.00 & 0.00 & 0.00 & 0.00 & 0.00 & 0.00 & 0.07 \\
\hline $\mathrm{Ti}$ & 0.11 & 0.08 & 0.09 & 0.13 & 0.07 & 0.26 & 0.08 & 0.05 & 0.01 & 0.04 & 0.09 & 0.06 & 0.13 & 0.05 & 0.04 & 0.05 & 0.19 & 0.18 & 0.06 & 0.06 \\
\hline $\mathrm{Fe}$ & 1.21 & 0.38 & 0.89 & 0.22 & 0.59 & 1.79 & 1.59 & 2.30 & & 2.42 & 0.87 & 1.91 & 1.31 & 1.55 & 1.69 & 1.72 & 1.28 & 1.04 & 1.70 & 2.00 \\
\hline $\mathrm{Mn}$ & 0.00 & 0.01 & 0.01 & 0.02 & 0.01 & 0.01 & 0.00 & 0.00 & 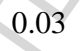 & 0.00 & 0.00 & 0.00 & 0.00 & 0.00 & 0.00 & 0.00 & 0.00 & 0.00 & 0.00 & 0.00 \\
\hline $\mathrm{Mg}$ & 1.56 & 2.23 & 1.86 & 2.42 & 2.19 & 0.83 & 1.36 & & 0.70 & 0.27 & 1.79 & 0.47 & 0.89 & 1.04 & 0.92 & 0.84 & 1.34 & 1.56 & 1.06 & 0.80 \\
\hline $\mathrm{Ca}$ & 0.07 & 0.22 & 0.03 & 0.19 & 0.16 & 0.12 & 0.12 & 0.02 & 0.02 & 0.03 & 0.09 & 0.05 & 0.05 & 0.03 & 0.13 & 0.11 & 0.27 & 0.19 & 0.08 & 0.04 \\
\hline $\mathrm{Na}$ & 0.85 & 0.55 & 0.90 & 0.76 & 0.77 & 0.79 & 0.80 & 0.82 & 0.63 & 0.83 & 0.80 & 0.73 & 0.72 & 0.81 & 0.75 & 0.73 & 0.70 & 0.75 & 0.91 & 0.80 \\
\hline K & 0.00 & 0.01 & 0.00 & 0.00 & 0.01 & 0.01 & 0.00 & 0.00 & 0.00 & 0.00 & 0.00 & 0.00 & 0.00 & 0.00 & 0.00 & 0.00 & 0.00 & 0.00 & 0.00 & 0.00 \\
\hline
\end{tabular}

The data are averages for single analyses (one per each sample). 
Table 3. $\delta^{11} \mathrm{~B}$ values of tourmaline samples from the Menderes Massif

\begin{tabular}{|c|c|c|c|c|}
\hline \multirow[b]{2}{*}{ Location } & \multirow[b]{2}{*}{ Sample Type } & Sample & \multirow[t]{2}{*}{ Repeat $\delta^{11} B$ values } & \multirow[t]{2}{*}{ Mean $\delta^{11} B$} \\
\hline & & No & & \\
\hline \multirow[t]{8}{*}{ Karahayıt } & tourmalinite & 71 & $+6.86 \pm 0.10,+6.24 \pm 0.12,+6.03 \pm 0.06$ & $+6.4 \pm 0.6$ \\
\hline & metasediments & 72 & $-5.20 \pm 0.15,-5.75 \pm 0.15,-6.08 \pm 0.14$ & $-5.7 \pm 0.6$ \\
\hline & tourmalinite & 7 & $+2.43 \pm 0.14,+2.14 \pm 0.05,+2.07 \pm 0.07$ & $+2.2 \pm 0.3$ \\
\hline & tourmalinite & 75 & $+0.92 \pm 0.09,+1.45 \pm 0.08,+1.43 \pm 0.13$ & $+1.3 \pm 0.4$ \\
\hline & tourmalinite & 75/D1 & $+5.65 \pm 0.10,+5.64 \pm 0.08,+5.90 \pm 0.08$ & $+5.7 \pm 0.2$ \\
\hline & tourmalinite & 76 & $+6.36 \pm 0.04,+6.32 \pm 0.05,+6.23 \pm 0.05$ & $+6.3 \pm 0.1$ \\
\hline & tourmalinite & 78 & $+5.07 \pm 0.11,+5.17 \pm 0.11,+5.50 \pm 0.09$ & $+5.3 \pm 0.3$ \\
\hline & tourmalinite & $78 / \mathrm{F}$ & $+4.84 \pm 0.10,+5.01 \pm 0.07,+5.80 \pm 0.18$ & $+5.2 \pm 0.7$ \\
\hline
\end{tabular}




\begin{tabular}{|c|c|c|c|c|}
\hline \multirow[t]{3}{*}{ Yeşilköy } & tourmalinite & $82 / 2$ & $+0.16 \pm 0.14,-0.12 \pm 0.09,-1.27 \pm 0.07$ & $-0.4 \pm 1.1$ \\
\hline & tourmalinite & $82 / 3$ & $+4.79 \pm 0.08,+5.55 \pm 0.10,+5.42 \pm 0.11$ & $+5.3 \pm 0.6$ \\
\hline & gneiss & 83/A & $-5.36 \pm 0.07,-5.46 \pm 0.08,-5.39 \pm 0.08$ & $-5.4 \pm 0.1$ \\
\hline \multirow[t]{2}{*}{ Irmadan } & gneiss & $\mathrm{I}-1$ & $-5.51 \pm 0.03,-5.55 \pm 0.03,-5.62 \pm 0.04$ & $-5.6 \pm 0.1$ \\
\hline & gneiss & I-3 & $-6.63 \pm 0.06,-6.72 \pm 0.07,-6.66 \pm 0.05$ & $-6.7 \pm 0.1$ \\
\hline \multirow[t]{4}{*}{ Labraunda } & metasediments & 4 & $-3.95 \pm 0.04,-3.98 \pm 0.04,-3.87 \pm 0.04$ & $-3.9 \pm 0.1$ \\
\hline & metasediments & 0 & $-8.18 \pm 0.04,-7.68 \pm 0.05,-7.95 \pm 0.03$ & $-7.9 \pm 0.4$ \\
\hline & metasedimen & 69 & $-6.12 \pm 0.13,-6.25 \pm 0.13,-6.37 \pm 0.16$ & $-6.2 \pm 0.2$ \\
\hline & metasediments & 70 & $-7.60 \pm 0.07,-7.94 \pm 0.04,-7.19 \pm 0.17$ & $-7.6 \pm 0.5$ \\
\hline Madran & tourmalinite & 58 & $-0.01 \pm 0.08,+0.11 \pm 0.19,-0.21 \pm 0.08$ & $-0.1 \pm 0.2$ \\
\hline Bafa & gneiss & BS-1 & $-7.15 \pm 0.09,-8.31 \pm 0.07,-8.56 \pm 0.06$ & $-8.1 \pm 1.1$ \\
\hline \multirow[t]{2}{*}{ Çine } & tourmalinite & 27 & $+6.70 \pm 0.05,+6.81 \pm 0.05,+6.03 \pm 0.04$ & $+6.5 \pm 0.6$ \\
\hline & tourmalinite & $01-136 / 2$ & $+6.53 \pm 0.06,+6.10 \pm 0.06,+5.91 \pm 0.09$ & $+6.2 \pm 0.4$ \\
\hline
\end{tabular}


51

tourmalinite

01-139

$+4.27 \pm 0.05,+4.17 \pm 0.05,+4.26 \pm 0.05$

$+4.2 \pm 0.1$

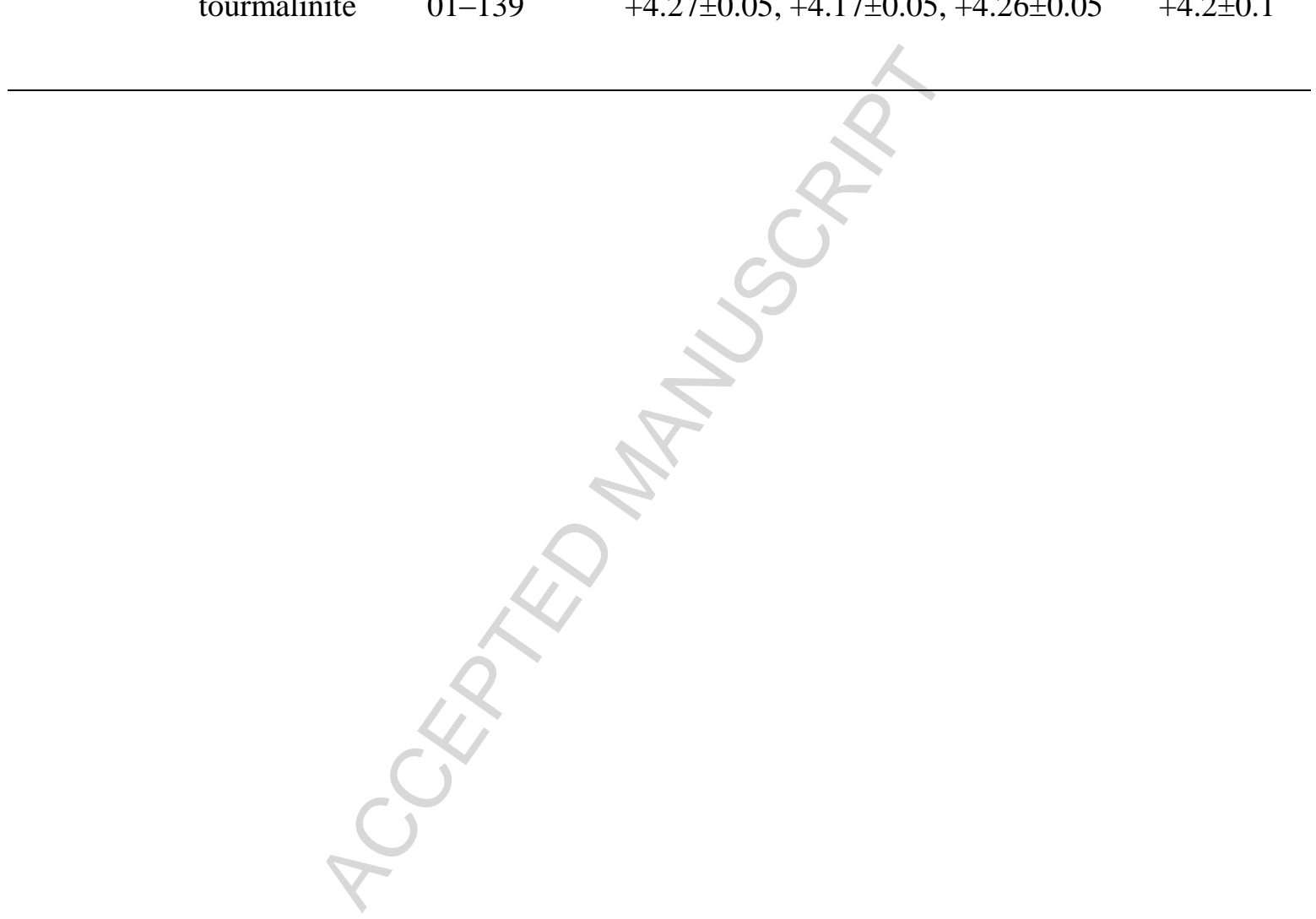


Table 4. Selected geochemical data for samples listed in Table 3.

\begin{tabular}{|c|c|c|c|c|c|c|c|c|c|c|c|c|c|c|c|c|c|c|}
\hline Sample & $\mathrm{Al}_{2} \mathrm{O}_{3}$ & $\mathrm{~K}_{2} \mathrm{O}$ & MgO & $\mathbf{N b}$ & La & $\mathrm{Ce}$ & Pr & Nd & $\mathrm{Sm}$ & Eu & Gd & $\mathbf{T b}$ & Dy & Ho & Er & Tm & $\mathbf{Y b}$ & Lu \\
\hline 71 & 9.07 & 0.22 & 2.20 & 4.9 & 162.0 & 315.0 & 45.8 & 167.0 & 30.4 & 5.8 & 17.8 & 2.2 & 10.1 & 1.5 & 3.3 & 0.43 & 2.4 & 0.31 \\
\hline 72 & 9.27 & 1.22 & 0.84 & 3.7 & 1.5 & 3.4 & 0.54 & 2.4 & 0.89 & 0.17 & 1.3 & 0.28 & 1.9 & 0.39 & 1.1 & 0.17 & 1.0 & 0.13 \\
\hline 74 & 16.81 & 0.12 & 4.53 & 6.5 & 2.9 & 7.1 & 0.93 & 3.8 & 1.1 & 0.36 & 1.6 & 0.29 & 1.9 & 0.39 & 1.1 & 0.17 & 1.1 & 0.17 \\
\hline $75 / \mathrm{C}$ & 10.12 & 0.04 & 1.65 & 17.8 & 103.0 & 213.0 & 26.1 & 88.2 & 18.1 & 3.8 & 15.0 & 2.6 & 15.1 & 2.8 & 7.3 & 1.0 & 5.9 & 0.75 \\
\hline 75/D1 & 12.96 & 0.09 & 3.30 & 1.7 & 6.8 & 14.4 & 2.2 & 9.9 & 4.6 & 1.7 & 9.4 & 1.9 & 12.9 & 2.6 & 7.6 & 1.1 & 6.8 & 0.90 \\
\hline 76 & 15.09 & 0.19 & 4.12 & 11.7 & 9.8 & 20.4 & 2.5 & 9.4 & 2.1 & 0.54 & 1.9 & 0.31 & 1.7 & 0.32 & 0.98 & 0.17 & 1.3 & 0.24 \\
\hline 78 & 9.82 & 0.03 & 1.60 & 3.6 & 6.3 & 10.4 & 1.6 & 6.5 & 1.5 & 0.52 & 1.8 & 0.34 & 2.2 & 0.47 & 1.3 & 0.21 & 1.4 & 0.21 \\
\hline $78 / \mathrm{F}$ & 3.59 & 0.45 & 0.66 & 1.4 & 11.8 & 20.3 & 3.0 & 11.8 & 2.7 & 0.78 & 2.8 & 0.46 & 2.4 & 0.37 & 0.86 & 0.12 & 0.74 & 0.10 \\
\hline $82 / 2$ & 7.25 & 0.11 & 1.20 & 3.9 & 13.0 & 24.6 & 3.3 & 14.5 & 3.5 & 0.94 & 3.4 & 0.51 & 2.7 & 0.49 & 1.3 & 0.19 & 1.3 & 0.21 \\
\hline $82 / 3$ & 7.69 & 0.08 & 1.33 & 1.4 & 6.0 & 13.6 & 1.8 & 6.9 & 1.4 & 0.36 & 1.5 & 0.26 & 1.4 & 0.29 & 0.89 & 0.15 & 1.1 & 0.17 \\
\hline 83/A & 24.18 & 1.82 & 2.35 & 4.7 & 11.3 & 24.4 & 3.1 & 12.1 & 3.5 & 0.33 & 3.2 & 0.54 & 3.1 & 0.60 & 1.7 & 0.25 & 1.5 & 0.22 \\
\hline I-1 & 13.86 & 0.55 & 0.20 & 3.6 & 5.6 & 14.1 & 1.8 & 6.9 & 2.0 & 0.46 & 2.0 & 0.37 & 2.1 & 0.34 & 0.84 & 0.11 & 0.64 & 0.07 \\
\hline $\mathrm{I}-3$ & 6.33 & 0.43 & 0.13 & 6.7 & 0.16 & 0.37 & 0.04 & 0.16 & 0.04 & 0.01 & 0.04 & 0.01 & 0.06 & 0.01 & 0.03 & 0.01 & 0.04 & 0.01 \\
\hline 4 & 11.16 & 0.06 & 2.55 & 0.4 & 1.7 & 3.5 & 0.43 & 1.6 & 0.48 & 0.10 & 0.88 & 0.26 & 2.4 & 0.67 & 2.5 & 0.48 & 3.7 & 0.58 \\
\hline 64 & 13.32 & 2.48 & 0.76 & 5.3 & 42.8 & 88.1 & 10.7 & 38.2 & 7.6 & 0.45 & 7.3 & 1.3 & 8.3 & 1.8 & 4.6 & 0.60 & 3.3 & 0.46 \\
\hline 69 & 11.58 & 3.36 & 0.15 & 1.1 & 2.5 & 7.3 & 1.0 & 3.7 & 1.6 & 0.07 & 1.8 & 0.48 & 3.1 & 0.52 & 1.3 & 0.20 & 1.2 & 0.12 \\
\hline 70 & 12.86 & 2.22 & 0.72 & 0.9 & 12.0 & 44.4 & 3.4 & 12.1 & 2.8 & 0.27 & 2.4 & 0.48 & 3.0 & 0.60 & 1.7 & 0.25 & 1.4 & 0.19 \\
\hline 58 & 15.21 & 0.15 & 3.85 & 0.6 & 2.7 & 4.2 & 0.47 & 1.6 & 0.37 & 0.18 & 0.48 & 0.10 & 0.64 & 0.14 & 0.36 & 0.05 & 0.32 & 0.05 \\
\hline BS-1 & 18.10 & 3.22 & 1.05 & 0.5 & 1.8 & 4.3 & 0.50 & 1.9 & 0.58 & 0.06 & 0.82 & 0.21 & 1.7 & 0.39 & 1.2 & 0.19 & 1.2 & 0.15 \\
\hline 27 & 23.61 & 0.94 & 3.95 & 5.9 & 6.6 & 13.5 & 1.8 & 7.0 & 1.6 & 0.55 & 1.5 & 0.24 & 1.5 & 0.32 & 1.0 & 0.16 & 1.2 & 0.19 \\
\hline $\begin{array}{l}01- \\
136 / 2\end{array}$ & 16.59 & 0.02 & 3.92 & 3.4 & 5.8 & 12.0 & 1.6 & 6.8 & 2.1 & 0.56 & 2.7 & 0.57 & 4.1 & 0.89 & 2.5 & 0.37 & 2.2 & 0.31 \\
\hline $01-139$ & 12.01 & 0.08 & 2.02 & 3.1 & 1.7 & 3.4 & 0.47 & 2.2 & 0.90 & 0.55 & 2.4 & 0.66 & 5.9 & 1.7 & 6.4 & 1.2 & 8.7 & 1.3 \\
\hline
\end{tabular}

$\mathrm{Al}_{2} \mathrm{O}_{3}, \mathrm{~K}_{2} \mathrm{O}$ and $\mathrm{MgO}$ concentrations are wt\%. All other concentrations are ppm. 
Table 5. Recommended and measured concentrations of geological standards

\begin{tabular}{c|cccccc}
\hline Standard & BIR1 rec & meas & JGb1 rec & meas & JB1A rec & meas \\
\hline & $15.35-$ & & $17.49-$ & & $14.45-$ & \\
$\mathrm{Al}_{2} \mathrm{O}_{3}$ & 15.50 & 15.56 & 17.66 & 17.46 & 14.51 & 14.44 \\
& $0.027-$ & & & & & \\
$\mathrm{K}_{2} \mathrm{O}$ & 0.030 & 0.026 & 0.24 & 0.25 & $1.40-1.42$ & 1.43 \\
$\mathrm{MgO}$ & $9.68-9.70$ & 9.83 & $7.83-7.85$ & 7.79 & $7.75-7.83$ & 7.85 \\
$\mathrm{Nb}$ & $0.5-0.6$ & 0.57 & $2.8-3.34$ & 3.2 & $26.9-27$ & 27.4 \\
$\mathrm{La}$ & $0.56-0.63$ & 0.59 & $3.6-3.74$ & 3.3 & $37.6-38.1$ & 37.9 \\
$\mathrm{Ce}$ & $1.85-1.95$ & 1.86 & $7.86-8.17$ & 7.9 & $65.9-66.1$ & 67.3 \\
$\mathrm{Pr}$ & $0.36-0.39$ & 0.37 & $1.13-1.14$ & 1.10 & 7.3 & 7.2 \\
$\mathrm{Nd}$ & $2.34-2.50$ & 2.30 & $5.47-5.65$ & 5.10 & $25.5-26$ & 26.3 \\
$\mathrm{Sm}$ & $1.07-1.11$ & 1.09 & 1.49 & 1.39 & 5.07 & 5.1 \\
$\mathrm{Eu}$ & $0.51-0.55$ & 0.53 & $0.62-0.63$ & 0.60 & $1.46-1.47$ & 1.49 \\
$\mathrm{Gd}$ & $1.80-1.98$ & 1.89 & $1.61-1.63$ & 1.60 & $4.54-4.67$ & 4.69 \\
$\mathrm{~Tb}$ & $0.35-0.38$ & 0.36 & $0.29-0.31$ & 0.27 & 0.69 & 0.71 \\
$\mathrm{Dy}$ & $2.5-4.0$ & 2.57 & $1.53-1.56$ & 1.68 & $3.99-4.19$ & 4.09 \\
$\mathrm{Ho}$ & 0.56 & 0.56 & $0.32-0.33$ & 0.35 & $0.64-0.71$ & 0.81 \\
$\mathrm{Er}$ & $1.65-1.71$ & 1.67 & $1.04-1.07$ & 0.97 & 2.18 & 2.22 \\
$\mathrm{Tm}$ & $0.25-0.26$ & 0.25 & $0.15-0.16$ & 0.15 & $0.31-0.33$ & 0.33 \\
$\mathrm{Yb}$ & $1.6-1.7$ & 1.66 & $0.97-1.06$ & 0.93 & 2.1 & 2.1 \\
$\mathrm{Lu}$ & $0.25-0.26$ & 0.25 & 0.15 & 0.14 & $0.32-0.33$ & 0.31 \\
\hline
\end{tabular}

$\mathrm{Al}_{2} \mathrm{O}_{3}, \mathrm{~K}_{2} \mathrm{O}$ and $\mathrm{MgO}$ concentrations as wt $\%$. All other concentrations as ppm. 